\title{
Piezoelectric Scaffolds as Smart Materials for Neural Tissue Engineering
}

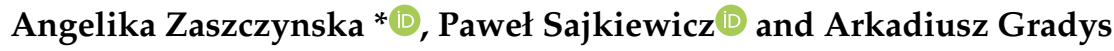 \\ Institute of Fundamental Technological Research, Polish Academy of Sciences, Pawinskiego 5b St., \\ 02-106 Warsaw, Poland; psajk@ippt.pan.pl (P.S.); argrad@ippt.pan.pl (A.G.) \\ * Correspondence: azasz@ippt.pan.pl
}

Received: 29 November 2019; Accepted: 5 January 2020; Published: 8 January 2020

\begin{abstract}
Injury to the central or peripheral nervous systems leads to the loss of cognitive and/or sensorimotor capabilities, which still lacks an effective treatment. Tissue engineering in the post-injury brain represents a promising option for cellular replacement and rescue, providing a cell scaffold for either transplanted or resident cells. Tissue engineering relies on scaffolds for supporting cell differentiation and growth with recent emphasis on stimuli responsive scaffolds, sometimes called smart scaffolds. One of the representatives of this material group is piezoelectric scaffolds, being able to generate electrical charges under mechanical stimulation, which creates a real prospect for using such scaffolds in non-invasive therapy of neural tissue. This paper summarizes the recent knowledge on piezoelectric materials used for tissue engineering, especially neural tissue engineering. The most used materials for tissue engineering strategies are reported together with the main achievements, challenges, and future needs for research and actual therapies. This review provides thus a compilation of the most relevant results and strategies and serves as a starting point for novel research pathways in the most relevant and challenging open questions.
\end{abstract}

Keywords: neural tissue engineering; piezoelectric scaffolds; smart materials; polymers

\section{Introduction}

The nervous system is the most complicated system in the body affecting the sensory and motor functions, when the system is damaged. Injuries of the central nervous system (CNS), i.e., brain and spinal cord, lead usually to permanent disability due to severe limitations for spontaneous regeneration of the CNS [1-9], leading to considerable socio-economic problems. For instance, 577 cases of traumatic brain injuries (TBI) per 100,000 people per year occurred in the U.S. alone, while, in Europe, the number of patients with diagnosed TBI was estimated at 262 per 100,000 [10]. Spinal cord injuries (SCI) are predominantly associated with irreversible loss of motor functions. In the U.S., 39 per 100,000 people were estimated to be SCI victims every year, mostly due to traffic accidents, jumping in pools, and falling from heights, while in Europe, the amount of SCI cases was 15 per 100,000 per year [11]. Regeneration of damaged neural tissue is often hindered by the presence of internal factors, such as tumor and scar tissue formation, which blocks its reconstruction. Up to date, there is no effective therapy for TBI and SCI, and surgery is able to inhibit lesion spreading only, while drug therapies have been so far focused mostly on pain relief. Hence, the current goal of CNS tissue engineering is to design a biomaterial enabling the effective outgrowth and differentiation of neural stem cells [12-14].

In recent decades, there has been increasing interest in research related to the development of smart materials [15]. Such materials are generally designed to respond to external stimuli (physical, chemical, mechanical) and behave similar to natural body tissues. One type of such smart materials is piezoelectric scaffolds, which can generate electrical signals in response to the applied stress [16]. Furthermore, they can stimulate the signaling pathways and thereby enhance the tissue regeneration 
at the impaired site. This applies especially to neural tissue, where the electrical charges are crucial for cellular activity. The major advantage of such piezoelectric scaffolds is that electrical potential can be generated non-invasively under the influence of mechanical forces, without the need to use invasive electrodes $[17,18]$.

It is known that obtaining piezoelectric scaffolds is possible using various paths, involving solvent casting, TIPS (thermally induced phase separation), freeze drying, or solution blowing [19]. One of most simple and effective methods of fabricating scaffolds in the form of ultrafine fibers with diameters ranging from a few nanometers to several micrometers is electrospinning. This relatively new method uses electric force applied in the form of a very high electrostatic field to draw charged threads from polymer solutions or melts up to the fiber. The process of electrospinning depends on various parameters, which are usually divided into three groups related to the process, material, and ambient parameters. This quite simple and inexpensive technique enables the formation of nano and submicron fibers, the properties of which differ substantially from the ones observed in the bulk materials [20].

For neural tissue engineering, a broad spectrum of synthetic and natural polymers has been studied in the form of electrospun scaffolds [21-30]. Nerve regeneration is a localized and complex biological phenomenon that makes the treatment of patients suffering from nervous system injuries difficult. Therefore, the application of piezoelectric polymers as nerve guidance conduits allows direct delivery of electrical stimulation of the cell's ingrowth with its electrical activity during mechanical deformation without the need for an external power source. Recent investigations have proven that neurons are extremely sensitive to electrical signals [30-39].

The aim of this paper is to summarize the studies on piezoelectric materials used for neural tissue engineering. The most used materials for neural tissue engineering strategies are reported together with the main achievements, challenges, and future needs for research and actual therapies. This review provides thus a compilation of the most relevant results and strategies and serves as a starting point for novel research pathways in the most relevant and challenging open questions.

\section{Mechanotransduction and Piezoelectricity in Living Organisms}

Mechanotransduction is any of the various mechanisms through which cells sense and convert mechanical stimuli into electrochemical activity. The well known direct element on the way between external stress transmitted through the extracellular matrix and the cells are s.c. stress activated channels, being membrane proteins capable of responding to mechanical stimuli, i.e., opening or closing, generating selective ion fluxes inside the cell, resulting in a cascade of signaling processes [40-43]. Other types of transmembrane ion channels are voltage gated channels, which are activated by changes in the electrical membrane potential near the channel (Figure 1) [44-46]. They play a key role in excitable cells such as neuronal and muscle tissues, allowing rapid and coordinated depolarization in response to triggering voltage change. Found along the axon and at the synapse, voltage gated ion channels directionally propagate electrical signals. Voltage gated ion channels are usually ion specific, for instance to sodium $(\mathrm{Na}+)$, potassium $(\mathrm{K}+)$, calcium $(\mathrm{Ca} 2+)$, and chloride $(\mathrm{Cl}-)$ ions. In the case of voltage gated channels, the natural piezoelectricity of the body elements is important for the generation of electrical charges under mechanical stress [47-50].

Mechanotransduction influences many aspects of biological functions. Nerves and neural stem cells (NSC) are sensitive to their surrounding environment, and they interact with this environment through cell surface receptors. Niche features such as substrate bound molecules, extracellular matrix (ECM) proteins, and properties such as stiffness and topography affect cell adhesion, survival, proliferation, migration, morphology, and differentiation [51-58]. 


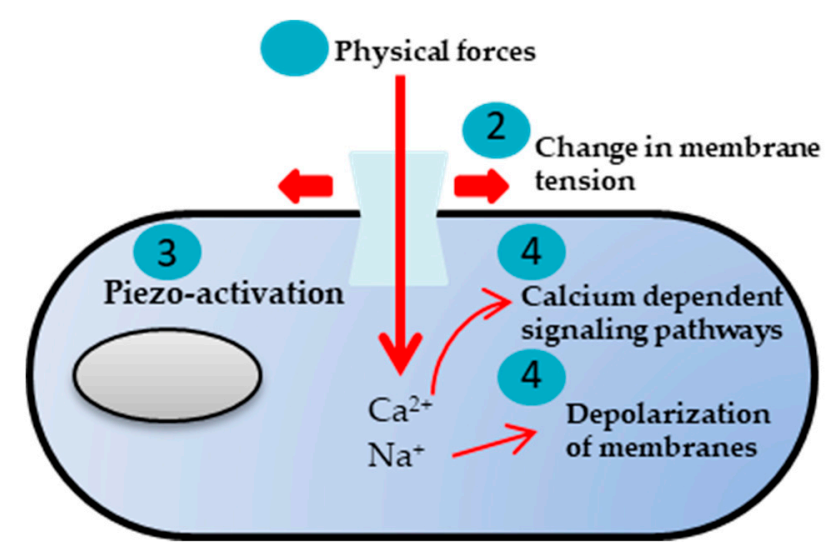

Figure 1. Various mechanical stimuli exerted on the cell induce changes in plasma membrane tension, eliciting piezo-channel openings (adapted from [59]).

The unique features of the nervous system present challenges to bioengineering research addressing nerve injuries. The nervous system is classified into the central nervous system (CNS) containing brain and spinal cord and the peripheral nervous system (PNS) created by the nerves leaving the CNS (Figure 2). The PNS somatic system transmits sensory and motor information for the CNS, while the autonomic one controls automatic functions (e.g., heart beating, blood pressure) [60-62].

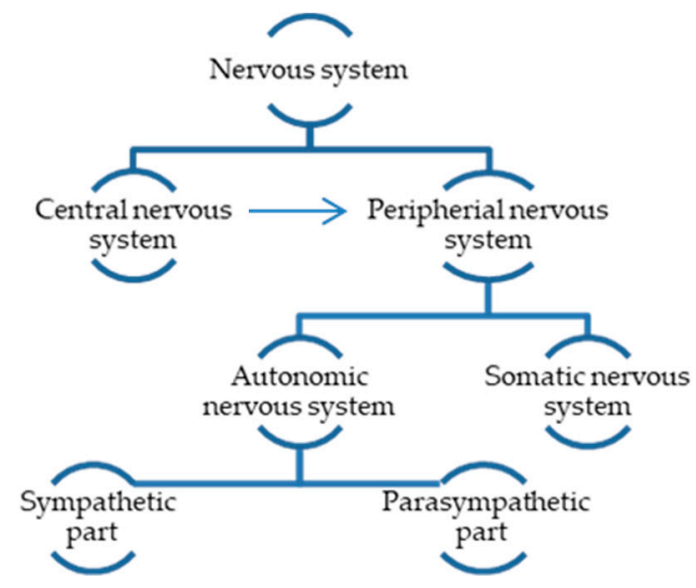

Figure 2. Classification of the nervous system.

The basic functional units in the nervous system having specific electrical properties are neurons and neuroglia (Figure 3), which enable effective transmission of the signals [63,64]. The plasma membrane in a non-excited state is characterized by the resting potential, the value of which is usually around $-70 \mathrm{mV}$ [65-67].

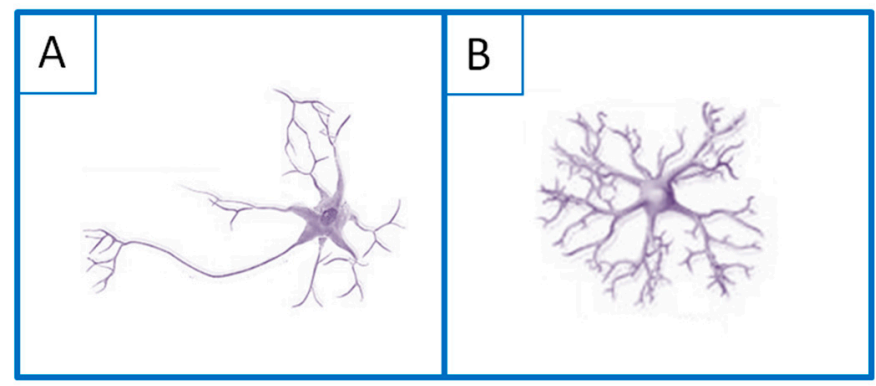

Figure 3. Schematic illustration of the basic units of the nervous tissue: (A) neuron and (B) neuroglia. 
The electrical properties of the neural cells are described by transmission of electrical signals. This phenomenon strongly affects cell behavior via activated ion influx/efflux across the cell membrane. Another phenomenon connected with the transmission of the signals in nerve cells is the action potential. This potential can be dispersed along the axon, which next releases the neurotransmitter (presynaptic ending), and the potential is spread further. A method to activate the action potential is the application of an electrical signal across the neuron. When a dendrite receives an electrical stimulus, the $\mathrm{Na}+$ channels open, and the potential changes from $-70 \mathrm{mV}$ to $-55 \mathrm{mV}$. When the potential changes up to $+30 \mathrm{mV}$, the depolarization process starts. Next, the $\mathrm{Na}+$ channels close, and the $\mathrm{K}+$ ones open, completing the depolarization process. When the potential reaches a value around $-90 \mathrm{mV}$, hyperpolarization begins, and the next step is the repolarization of the membrane, which allows receiving another stimulus through the neuron (Figure 4). After the hyperpolarization, the $\mathrm{Na}+$ and $\mathrm{K}+$ channels restore the potential state at the level of $-70 \mathrm{mV}$ [68].

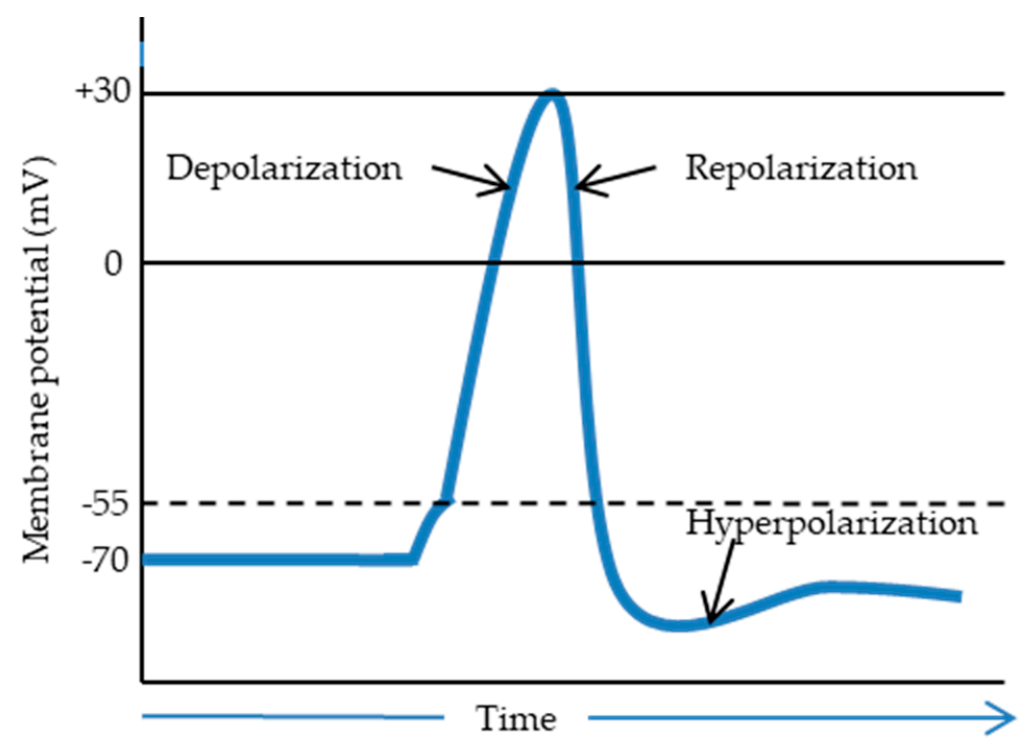

Figure 4. Potential difference in neural transmission as a function of time (adapted from [69]).

Signal transmission is the integral objective of neurons; hence, they are influenced by electrical stimuli. Many research groups have tried to explain the effect of electric stimulation on nerve regeneration. One group described the general effect of electrical stimulation on neurons [70]. Another group studied the activation of the growth controlling transport processes across the plasma membrane and the electrophoretic accumulation of the surface molecules responsible for neurite growth or cell substratum adhesion [70]. Freeman et al. [71] suggested that changes in ionic currents comprise a possible phenomenon that can affect nerve cells, while another thesis [72] described the effect of electrical stimulation on the synthesis of protein and stimulation of the neurite outgrowth in vitro. Furthermore, the authors in [73] postulated that pheochromocytoma in rat neuronal cells (PC12 cells) was electrically activated, while in [74], it was shown that the electrical stimulation increased the adsorption of fibronectin, which explains the enhanced neurite extension on electrically stimulated polypyrrole films. Additionally, nerve cells in the presence of electrical stimulation showed an extensively elongated morphology. In general, tensile/compression forces acting on the piezoelectric scaffolds generate the electrical stimulation and transfer it to the surrounding cells, promoting the cell signaling pathways, responsible for growth factor synthesis (Figure 5) [75]. 


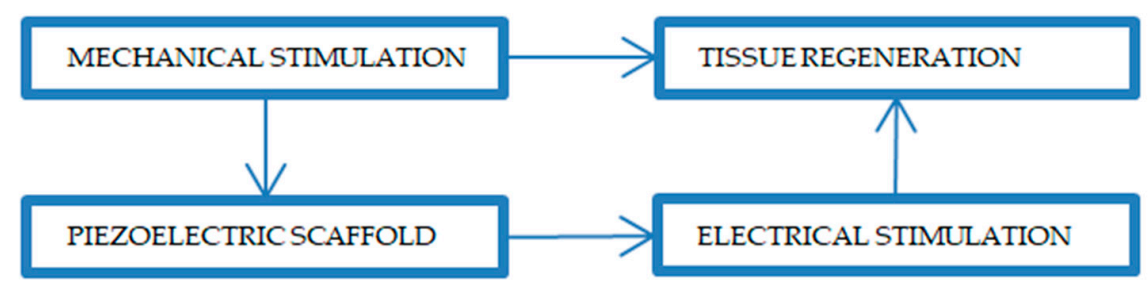

Figure 5. Representative scheme of tissue regeneration in response to the mechanical and electrical stimulation on the piezoelectric scaffold.

In 1940, Martin [76] reported the first piezoelectric phenomena in biological tissues, when he observed electric potentials from a bundle of wool compressed by two brass plates. The main component of hair, horns, and wool is keratin in the form of an alpha-helix. It is known that the piezoelectricity of this tissue is due to the highly ordered arrangement and natural polarization of the alpha-helices, which are stabilized by hydrogen bonds between the hydrogen in the amine group and the oxygen in the carbonyl group [77-82] (Figure 6).

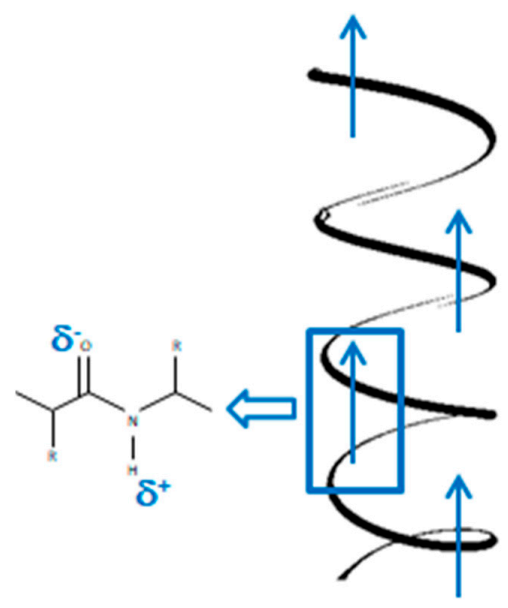

Figure 6. Scheme of permanent polarization in the $\alpha$-helix.

The results of investigations on the piezoelectric properties of biological tissues have been extensively reported [83-85]. The piezoelectric phenomenon has been confirmed in a variety of biological tissues, such as bone and tendons, due to the presence of highly ordered crystalline fibrillar structures such as collagen, chitin, and elastin [86-90].

The piezoelectric effect, by definition, is described by four piezoelectric coefficients $\mathrm{d}$, e.g., and h:

$$
\begin{gathered}
\mathrm{d}=(\delta \mathrm{D} / \delta \mathrm{X})^{\mathrm{E}}=(\delta \mathrm{x} / \delta \mathrm{E})^{\mathrm{X}} \\
\mathrm{e}=(\delta \mathrm{D} / \delta \mathrm{x})^{\mathrm{E}}=-(\delta \mathrm{X} / \delta \mathrm{E})^{\mathrm{X}} \\
\mathrm{g}=-(\delta \mathrm{E} / \delta \mathrm{X})^{\mathrm{D}}=(\delta \mathrm{x} / \delta \mathrm{D})^{\mathrm{X}} \\
\mathrm{h}=-(\delta \mathrm{E} / \delta \mathrm{x})^{\mathrm{D}}=-(\delta \mathrm{X} / \delta \mathrm{D})^{\mathrm{X}}
\end{gathered}
$$

which relate the electrical variables: $\mathrm{D}$ (electric displacement) and $\mathrm{E}$ (electric field) with the mechanical variables: $X$ (stress) and $x$ (strain). The first terms in Equations (1)-(4) describe the direct piezoelectric effect, while the second terms the converse piezoelectric effect. The subscripts relate to zero constraints of $\mathrm{E}, \mathrm{D}, \mathrm{X}$, or $\mathrm{x}$. Moreover, each of the coefficients $\mathrm{d}, \mathrm{e}, \mathrm{g}$, and $\mathrm{h}$ is a third rank tensor expressed as a $3 \times 6$ matrix. The piezoelectric coefficients are indicated in the scheme in Figure 7 , along with the coefficients $\varepsilon$ (dielectric permittivity) and $c$ (elastic constant) relating to each other the electrical variables $\mathrm{D}$ and $\mathrm{E}$ as well as the mechanical variables $\mathrm{X}$ and $\mathrm{x}$, respectively. 


\section{PIEZOELECTRICITY}

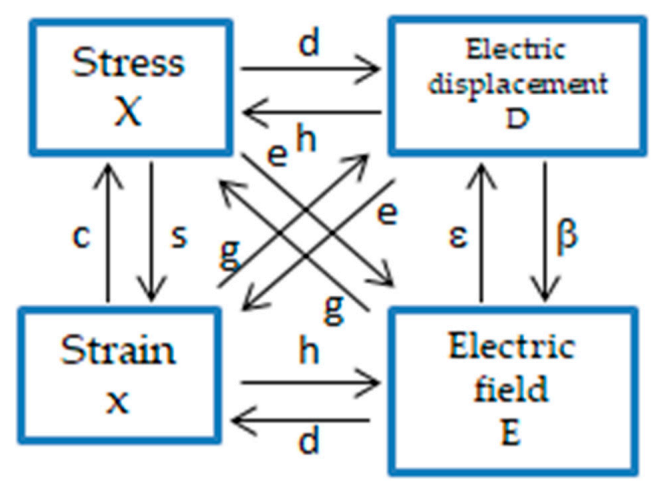

Figure 7. Definition of the piezoelectric coefficients (adapted from [91]).

The ratios of the coefficients $\varepsilon$ and $c$ at zero constraints of $\mathrm{x}, \mathrm{X}, \mathrm{E}$, and $\mathrm{D}$, as indicated by superscripts, define the electromechanical coupling coefficient, $\mathrm{K}$, as given by:

$$
\varepsilon^{\mathrm{x}} / \varepsilon^{\mathrm{X}}=\mathrm{c}^{\mathrm{E}} / \mathrm{c}^{\mathrm{D}}=1-\mathrm{K}^{2}
$$

which characterizes the efficiency of the conversion of mechanical energy to electrical energy and vice versa in the direct and converse piezoelectric effect, respectively. The piezoelectric coefficients may be determined through the direct and converse effects or the piezoelectric resonance, providing directly $\mathrm{d}, \mathrm{e}, \mathrm{g}$, and $\mathrm{h}$ coefficients or the efficiency coefficient $\mathrm{K}$, respectively. The results are complementary, as they cover the low (below audio) and the high frequency ranges (above $10 \mathrm{kHz}$ ) [91].

The piezoelectric effect is exhibited in all of the amino acid crystals, excluding alpha glycine alone. The piezoelectric coefficients found in biological materials are generally low, typically in the range of $0.1-10 \mathrm{pm} / \mathrm{V}$ (the converse effect) with the values for collagen as low as $0.2-2.0 \mathrm{pC} / \mathrm{N}$ (the direct effect). The piezoelectric properties for the most relevant natural materials are reported in Table 1.

Table 1. Natural polymers with the piezoelectric response.

\begin{tabular}{cccc}
\hline \multicolumn{2}{c}{ Natural Polymers } & Piezoelectric Coefficient $-\mathbf{d 1 4}(\mathrm{pC} / \mathbf{N})$ & Ref. \\
\hline \multirow{3}{*}{ Collagen } & Skin & 0.2 & {$[92]$} \\
& Bone & 0.7 & {$[92]$} \\
& Tendon & 2.0 & {$[93]$} \\
\hline \multirow{2}{*}{ Keratin } & Horn & 1.8 & {$[94]$} \\
& Wool & 0.1 & {$[94]$} \\
\hline \multirow{2}{*}{ Fibrin } & Salmon DNA & 0.07 & {$[93]$} \\
\hline
\end{tabular}

\section{Scaffolds: Stimuli Responsive (Piezoelectric) vs. Passive}

It is generally perceived that the tissue engineering scaffolds should mimic natural existing extracellular matrix (ECM), having similarities as much as possible to the native tissues they are intended to replace in terms of the chemical composition, morphology, physical and mechanical properties, as well as biocompatibility and biodegradability. In detail, the fundamental requirements, that need to be taken into account during scaffold designing are: scaffold biocompatibility, appropriate degradation time in the case of biodegradable materials, the presence of interconnected pores in an appropriate size range, scaffold thickness, mechanical properties, and convenience of use during a surgical procedure $[95,96]$.

It is well known that ECM is a highly dynamic structure; it is constantly being remodeled, either enzymatically or non-enzymatically, and its molecular components are subjected to various modifications. However, most of the recent artificial scaffolds remain passive, i.e., non-stimuli 
responsive to the external changes of the environment (static scaffolds) [97]. Moreover, conventional static scaffolds, even conductive, largely disturb the natural signaling pathways, due to their rigidity towards the signal conduction. Thus, there is a high need for smart, stimuli responsive scaffolds, which can generate and transfer the bioelectric signals analogously to the native tissues for appropriate physiological functions. Piezoelectric materials can generate electrical signals in response to the applied stress, which can be imposed even by attachment and migration of cells or body movements [98]. Using piezoelectric materials as tissue engineering scaffolds enables electrical stimulation without the need for electrodes, an external source of electricity, or implanting batteries. Such scaffolds should possess proper architecture and mechanical properties in addition in order to support cell adhesion, proliferation, and differentiation. The size of pores should be controllable and adjusted in order to enable diffusion of the metabolite, but also for appropriate cell adhesion to the biomaterial. Ninety percent porosity and a pore size in the range of 10-100 $\mu \mathrm{m}$ seem to be the most suitable for neuron growth. Scaffolds characterized by $85-90 \%$ porosity may be obtained by the electrospinning technique [99]. Such porosity is reported as supporting cellular migration and controlled diffusion of cells, metabolites, and medium, being important for cells organization, differentiation, and survival [100,101].

Obtaining a scaffold that would be biocompatible, biodegradable, conducting, and resistant to infection in order to provide neurite outgrowth is a complex task [102]. Successful nerve regeneration requires tissue engineered scaffolds not only for mechanical support of growing neurites and impediment of the ingrowth of fibrous scar tissues, but also to send biological signals to guide the axonal growth cone to the distal stump. Polymers are in general that materials that have been extensively used for creating suitable scaffolds for neural tissue [103].

Table 2 summarizes the main works on the application of piezoelectric potential scaffold materials and their applications.

Table 2. Piezoelectric materials in nerve tissue engineering.

\begin{tabular}{|c|c|c|c|}
\hline Material Type & Scaffold Design & Cells Type Used & Ref. \\
\hline \multirow{9}{*}{ Polyvinylidene Fluoride (PVDF) } & Film* & Spinal cord neurons & [104] \\
\hline & Film* & Mouse neuroblastoma cells & [105] \\
\hline & Channels & Mouse sciatic nerve model & [106] \\
\hline & Tubes & Wistar rats & [107] \\
\hline & Membranes & Neuronal cells & [108] \\
\hline & Films & Stem cells & [109] \\
\hline & Nanosheets * & Rat neuronal cell line & [110] \\
\hline & Fibers* & Osteoblasts MG-63 cells & [111] \\
\hline & Fibers & Mesenchymal stem cells & [112] \\
\hline \multirow{6}{*}{$\begin{array}{c}\text { Poly[(vinylidene } \\
\text { fluoride-co-trifluoroethylene] } \\
\text { (PVDF-TrFE) }\end{array}$} & & Poietics normal human neural progenitors & [113] \\
\hline & Fibers & Dorsal root ganglion & [114] \\
\hline & Films & Poietics normal human neural progenitors & [113] \\
\hline & Membranes* & Osteoblasts SaOS-2 cells & [115] \\
\hline & Tubes & In vivo implementation: rat sciatic nerves & [116] \\
\hline & Fibers * & Preosteoblasts & [117] \\
\hline \multirow{5}{*}{$\begin{array}{l}\text { Poly(3,4ethylenedioxythiophene) } \\
\text { (PEDOT) }\end{array}$} & Films & Fibroblast growth factor (bFGF) & [118] \\
\hline & Films * & - & [119] \\
\hline & Films* & Neural stem cells & [120] \\
\hline & Films & Neural stem cells & [121] \\
\hline & Nanofibers* & Brain neuroglioma cells & [122] \\
\hline \multirow{5}{*}{$\begin{array}{l}\text { Polylactic acid } \\
\text { (PLLA) }\end{array}$} & \multirow{4}{*}{ Fibers } & Sprague-Dawley rats & [123] \\
\hline & & PLLA blends for vascular differentiation in vitro & [124] \\
\hline & & Neural differentiation and growth in vitro & $\begin{array}{l}{[125,} \\
126]\end{array}$ \\
\hline & & PLLA blends for bone formation in vitro & [127] \\
\hline & +PANi fibers * & Nerve stem cells & [128] \\
\hline $\begin{array}{l}\text { Poly(3-hydroxybutyrate-co-3-hydroxyvalerate) } \\
\text { (PHBV) }\end{array}$ & Fibers* & Human mesenchymal stem cell & [129] \\
\hline \multirow{2}{*}{ Collagen } & Fibers & Schwann cells & [130] \\
\hline & 3D gel matrices & Embryonic rat cerebral cortices & [131] \\
\hline $\mathrm{BaTiO} 3$ & + PVDF matrix & Osteoblasts & [132] \\
\hline
\end{tabular}




\section{Application of Piezoelectric Biomaterials in Neural Tissue Engineering}

\subsection{Piezoceramics}

The earliest studied piezoelectric material group is the piezoceramics. The first applications were dated since around 1950, and since then, they have been widely used in the industry [133]. Wersing et al. [134] conducted the pioneering study on porous piezoceramics, as well as provided the basics in the theory and initial measurements [135]. Currently, there is a great need for lead-free piezoelectric materials, but the most practical ceramics are still based on lead zirconate titanate. Rat cortical neurons cultured on PZT slides coated with poly-L-lysine grew significantly longer axons, despite a decrease in cell number. Furthermore, the frequency and amplitude of the excitatory postsynaptic currents increased, suggesting that piezoelectricity could have augmented neuronal activity [136]. It is worth mentioning that piezoceramics are used for medical applications, especially medical actuators, transducers, and sensors. Due to allergic reactions, piezoceramics are not used in pure solution for medical implants. The innovative systems for medical applications are composites based on polymer matrices, with ceramic fillers, in the form of fibers [137-139]. To achieve bone defect repair, Lopes et al. [140] incorporated barium titanate nanoparticles into polymer matrix, which induced relatively high spontaneous polarization. Moreover, this system is characterized by reduced fragility and can be used as electroactive scaffolds [141].

\subsubsection{Barium Titanate}

The first piezoelectric effects in ceramics were discovered during poling of BT and led to the wide use of this material group, also as an addition in scaffolds, especially in medical applications [142,143]. Piezoceramics based on barium titanate exhibit low toxicity compared to lead based piezoelectric materials. For their high strain, they are among the most investigated groups of piezoceramics. BT nanoparticles have demonstrated cytocompatibility, even at higher concentrations of $100 \mu \mathrm{g} / \mathrm{mL}$ [144]. Ciofani et al. [145] demonstrated that PLGA matrix with the addition of BT nanoparticles supports the cell proliferation and attachment of osteocytes and osteoblasts. Additionally, the incorporation of barium titanate nanoparticles into the polymeric matrix improves the mechanical properties of the composite scaffold [146] and promotes cellular activity in tissue engineering applications [147].

\subsubsection{Boron Nitride}

Boron nitride $(\mathrm{BN})$ based nanomaterials play a significant role in nanotechnology owing to their conductivity, mechanical strength, and high thermal stability $[148,149]$. The most known boron nitride piezo-materials are in the shape of nanotubes, and with increased cytocompatibility, they can be used in tissue engineering [150] and drug delivery, due to their high piezoelectric properties [151-155]. It has been proven that boron nitride nanotubes have a positive influence on the adhesion of cells [156]. Among all the properties of boron nitride nanotubes (BNNTs), their excellent piezoelectricity is the most important for using them as nanovectors to deliver electrical or mechanical signals within cells [157].

\subsubsection{Zinc Oxide}

Zinc oxide based piezoceramics are widely used due to their asymmetric hexagonal wurtzite structure and polar crystal surface. They have found application as piezoelectric nanogenerators, because of the easy fabrication [158]. $\mathrm{ZnO}$ in the shape of nanostructures is biocompatible [159]. It has been suggested that with $\mathrm{ZnO}$ size, its cytotoxicity increases, which has an influence on the levels of reactive oxygen species, reduces the mitochondrial membrane potential, and induces the production of interleukin in human cells. Additionally, it has been reported that chemical modification can reduce toxicity, providing a way for use in biomedical applications $[160,161]$. 


\subsection{Piezopolymers}

Piezoelectric polymers are a relatively new class of materials allowing the formation of electrical charges under mechanical stimulation in the absence of additional energy sources or electrodes [162]. Additionally, which is very important from the biomedical point of view, polymers are able to meet the requirements of biocompatibility and biodegradability, which is very crucial for new types of implants in regenerative medicine [163]. Further, their big advantage is the very high processing flexibility, which differentiates them from inorganic materials [164].

\subsubsection{Synthetic Polymers}

\section{Polyvinylidene Fluoride}

Among various piezoelectric polymers, PVDF is widely investigated, primarily because of its high piezoelectricity, processability, good chemical resistance, thermal stability, and good mechanical properties as compared to other piezoelectric polymers. PVDF may exist in at least five crystalline polymorphic phases, among which the $\beta$-phase shows the highest piezoelectricity, which reaches $20 \mathrm{pC} / \mathrm{N}$ (Figure 8) [165,166].

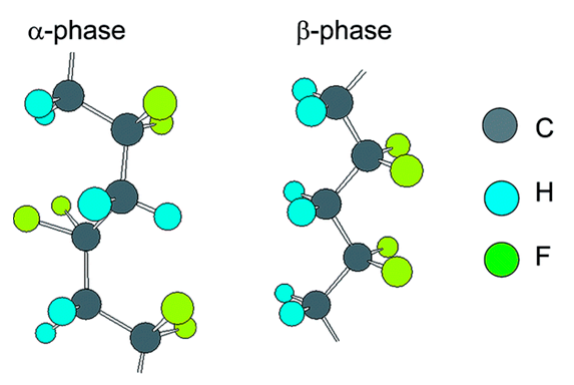

Figure 8. Structures of alpha and beta PVDF.

PVDF macromolecules may take various chain conformations and arrangement of $\mathrm{CH}_{2}-\mathrm{CF}_{2}$ molecular dipoles, resulting in various net dipole moments. A strong electric moment in the PVDF monomer unit arises from the strong electro-negativity of fluorine atoms as compared to hydrogen atoms. In the case that polymer chains are packed into crystals to form parallel dipoles, the crystal has a non-zero net dipole moment [89-94]. Such a molecular arrangement is observed in the $\beta, \gamma$, and $\delta$ phases, the first one showing the strongest dipole moment, due to the all-trans conformation. In the case of other chain conformations: TGTG- and $\mathrm{T}_{3} \mathrm{GT}_{3} \mathrm{G}-$, parallel dipole moment arrangement, as in the $\delta$ and $\gamma$ phases, respectively, leads to lower polarity; in the case of the same conformations, antiparallel chain dipole arrangement leads to the zero net dipole moment as in the $\alpha$ and $\epsilon$ phases [167].

The piezoelectricity of PVDF is phase content dependent, which hinges on the processing conditions. Obtaining a particular crystal phase is possible using various paths, involving melt or solution crystallization, annealing (also at high pressure), mechanical drawing, or electrical poling. The presence of polar phases is very important, in particular, due to its bioelectrical effect of the stimulation of the nervous system, holding promise for effective tissue regeneration $[168,169]$.

As regards the most polar $\beta$-phase, it may be obtained, for example, by annealing at very high pressure from the $\alpha$-phase, by poling at a very high electrical field from the $\alpha$-phase or $\delta$-phase [170] or drawing from the $\gamma$-phase [171]. In order to increase the content of polar phases, various methods are reported: melt-recrystallization [172], poling under a high electric field [173], application of high pressure [174], mechanical stretching [175], and the addition of nanoparticles, graphene, and nanowires [176].

The desire to use PVDF in piezoelectric scaffolds in tissue engineering requires the use of fabrication techniques that allow obtaining the proper morphology and high polar phase content responsible for the high piezoelectricity [177]. One of the promising fabrication techniques to fulfil both expectations is 
the electrospinning technique. Many publications were devoted to electrospinning of PVDF nanofibers from solution [178], determining the effect of processing parameters on the structure and properties of nanofibers and the characteristics of nonwoven nanofiber [179]. The content of the $\beta$-phase in PVDF was studied from the point of view of the applied voltage and rotation speed of the rotational collector. The collector rotational speed relates to the mechanical deformation, which is known to promote the formation of the polar phase [180]. Liu et al. [181] formed nanofibers with different rotational speeds of the collector: 900, 1100, 1300,1500, 1700 and $1900 \mathrm{rpm}$. XRD diffraction showed a peak around 20.6-20.9 deg, which belonged to the $\beta$-phase, while the $\alpha$-phase peaks disappeared. They received piezoelectric PVDF fibers with a small diameter, smooth surface morphology, and appropriate $\beta$-phase at a velocity of $1900 \mathrm{rpm}$. Recent works support the view that increasing of the rotational speed of the collector induces a higher content of the piezoelectric $\beta$-phase [182-184].

The hydrophobicity of PVDF is a problematic issue in neural tissue engineering. In order to reduce it, numerous research works have been conducted. In order to enhance the hydrophilic, as well as mechanical and electrical properties, PVDF has been modified by the addition of different nanostructures: nanoparticles [185-187], inorganic nanoparticles [188,189], nanotubes [190], and also by the addition of different polymers such as polyethylene glycol (PEG) [191] and polyvinyl alcohol (PVA) [192]. The addition of nanoparticles, especially metallic ones, improves the chemical, physical, and optical properties [193], while diamond nanoparticles have no significant impact on neuroblastoma cell morphology [194]. The incorporation of these nanostructures into a polymer piezoelectric scaffold can positively affect the nerve tissue. Additionally, modification of the surface can increase the neuron length and number of synaptic connections [195,196].

Arinzeh et al. $[113,114]$ tested the piezoelectric scaffolds' potential for promoting in vitro neural differentiation of human neural stem cells, thus demonstrating their applicability in neural tissue engineering. The authors in [197] extended the above studies by applying mechanical vibration, while generating electric fields to induce the piezoelectric effect in piezopolymers. The activation of the piezoelectric effect can be achieved by choosing various sources of mechanical stimulation, including vibration plates, sound, and ultrasound (US) [198,199]. Hoop et al. [85] investigated the influence of the piezoelectric PVDF substrate on supporting neural differentiation under dynamic stimulation. The results showed that the applied ultrasonic waves were sufficient to induce polarization in piezoelectric PVDF sheets and resulted in differentiation of PC12 cells. Piezoelectric PVDF can influence neuronal differentiation and neurite outgrowth of mouse neuroblastoma cells [200]. Electric fields have been shown to influence the growth and orientation of neurons in vitro, whereas the electric field was generated via electrodes [201]. Other studies have been reported successful neural stimulation in various piezoelectric systems, especially piezoelectric micro- and nano-fibers [202,203].

It was shown that the long term application of piezoelectric stimulation on neurons induces the number, length, and branching of neural cells with respect to non-stimulation conditions. No effects on neurite regeneration were observed when vibrations were applied to non-piezoelectric materials (e.g., mechanical stimulation of neurons) [204-206].

Poly-Vinylidene Fluoride-Trifluoroethylene

Among the piezoelectric materials, this copolymer demonstrated the highest electroactive properties with a piezoelectric coefficient as high as $30 \mathrm{pC} / \mathrm{N}$ [207]. PVDF-TrFE forms the $\beta$-phase through copolymerization without the need for mechanical stretching or drawing [208]. In the case of additional annealing, mechanical stretching, or electrical poling, it is possible to further increase the crystallinity and alignment of the CF2 dipoles, thereby inducing higher piezoelectricity as compared to homopolymer PVDF, dependent on the TrFE content [209]. Electrospun PVDF-TrFE fibrous scaffolds showed higher crystallinity and $\beta$-phase content as compared to the starting powder material for neural and bone tissue engineering [101-104]. PVDF-TrFE and barium titanate piezoelectric composite membrane has been reported as a charge generator to promote bone regeneration [106]. 
PVDF-TrFE piezoelectric fibrous scaffolds were used to study their influence on neural repair. Many investigations reported a positive influence of PVDF-TrFE scaffolds on nerve cell growth and differentiation [210]. Lee et al. [114] fabricated a PVDF-TrFE piezoelectric electrospun scaffold with different orientations of the fibers, randomly and aligned. It was shown that the scaffold with aligned fibers had the highest potential in neural tissue engineering, especially in neurite outgrowth of dorsal root ganglion neurons. It was observed that PVDF-TrFE scaffolds can promote the formation of mature neural cells exhibiting neuron-like characteristics, while aligned fibers can promote primary neuron extension and can direct the neurite outgrowth [211].

Nerve guidance channels may be built using PVDF-TrFE for neural regeneration [212]. In this study, poled (negatively charged and positively charged) and unpoled channels were used. After four weeks, it was observed that the positively poled channels increased the number of regenerated nerves.

In muscle regeneration, the charge at the surface of PVDF films influences the cell proliferation [213]. However, until now, studies with specific dynamic conditions for piezoelectric PVDF-TrFE with mechanical or electrical stimulation have not been conducted.

Poly-3-Hydroxybutyrate-3-Hydroxyvalerate

PHBV is a polyester with a low piezoelectric coefficient (1.2 pC/N) [214]. It is a thermoplastic produced by many bacteria as an intracellular reservoir of carbon and energy. This polyester is also biodegradable, biocompatible, and exhibits strong mechanical properties, which allow using PHBV as a scaffold in biomedicine and as a biosensor $[215,216]$. PHBV has a comparable piezoelectric potential to that of bone, which can facilitate bone growth and healing [217,218]; thus, it can be used in the form of a composite with the addition of hydroxyapatite for bone tissue engineering. PHBV has been studied for neural tissue engineering, as a support for neuronal cell growth and axon dendrite polarization [219]. In the form of electrospun aligned PHBV fibers, with the addition of collagen, it can be used as a substrate for nerve tissue engineering [220-222].

Poly-L-Lactic Acid

Poly-L-lactic acid is a biodegradable and biocompatible polymer, with a piezoelectric coefficient of $-10 \mathrm{pC} / \mathrm{N}$ [223]. Fukada et al. demonstrated that implantation of PLLA can promote bone growth in the response of its piezoelectric polarization [93]. PLLA with a structure similar to natural ECM may be used as a biomaterial in various biomedical applications [224]. Aligned PLLA nanofibrous scaffolds coated with graphene oxide promote neural cell growth [225]. Finally, the addition of iron oxide nanoparticles supports extending neurites along electrospun PLLA microfibers $[226,227]$.

\subsubsection{Natural Biopolymers}

Natural polymers are gaining more importance in tissue engineering because of their biodegradability and low toxicity. In general, many biopolymers exhibit piezoelectricity. As an example, we show some polysaccharides and proteins with relatively strong piezoelectricity.

\section{Cellulose}

Cellulose with a piezoelectric coefficient of $0.10 \mathrm{pC} / \mathrm{N}$ is a widely investigated natural polymeric material. Cellulose is a linear homopolymer of glucose with high biocompatibility [228-234]. It is used in different shapes and forms: membrane sponges, microspheres, and non-woven, woven, or knitted textiles. Cellulose has been investigated in the tissue engineering of bones [235,236], cartilage [237], for connective tissue formation [238], as a drug delivery system [239], and as a scaffold for growing functional cardiac cell constructs in vitro [240]. One of the important derivatives of cellulose is methylcellulose (MC), presenting in general good solubility in water, particularly at low temperatures, being dependent on the degree of methyl substitution and the distribution of methoxy groups. Collectively, these data indicate that MC is well suited as a biocompatible injectable scaffold for the repair of brain defects [241-243]. Gelatin coated nanoparticles contained in cellulose acetate/PLA 
scaffolds showed higher cell viability than uncoated scaffolds, and they acted as a nerve guidance conduit for sciatic nerve defects in vitro and in vivo [244], while a gelatin/chitosan/PEDOT hybrid scaffold enhanced the neurite growth of PC12 cells and promoted neuron-like cell adhesion and proliferation [245].

\section{Chitin and Chitosan}

Chitin is a natural polysaccharide with a piezoelectric structure with a low piezoelectric coefficient in the range from 0.2 to $1.5 \mathrm{pC} / \mathrm{N}$ [246]. It is a natural component of the cuticles of crustaceans, insects, and mollusks. Since it is hydrophilic and biocompatible, chitin is used for biomedical applications, promoting cell adhesion, proliferation, and differentiation [247].

Chitosan is a biodegradable and biocompatible linear polysaccharide obtained by partial deacetylation of chitin. It has been extensively investigated for the preparation of porous scaffolds for cartilage tissue engineering [248]. However, the low mechanical properties of scaffolds prepared from chitosan make its clinical application problematic. An effective method to overcome chitosan's drawbacks is to blend it with synthetic polymers [249-252]. Skop et al. designed biocompatible chitosan microspheres for the delivery of neural stem cells and growth factors for CNS injuries [253]; another group designed chitosan particles loaded with the drug piperine, reported to have neuroprotective potential against Alzheimer's disease, which successfully targeted specific areas of the brain [254]. Chitosan nanoparticles have also been developed for intranasal delivery of therapeutic agents to the brain $[255,256]$. Aligned PCL/chitosan fibers supported PC12 cells adhesion and growth, enhancing neurite extension along the fiber orientation [257]. PLGA/chitosan scaffolds guided neuronal differentiation for peripheral nerve regeneration both in vitro and in vivo $[258,259]$.

\section{Collagen}

This is a natural piezoelectric material with a piezoelectric coefficient in the range from 0.2 to $2.0 \mathrm{pC} / \mathrm{N}$ [260]. Research has been reported on the application of collagen scaffolds in bone healing [261-264]. Furthermore, collagen-calcium phosphate composites have been reported for cartilage tissue engineering [265]. Similarly, collagen-hydroxyapatite piezoelectric composite scaffolds have been proven to be suitable for cellular growth [266]. Collagen scaffolds with the addition of chitosan have been tested in adipose tissue regeneration. Adipocytes were seeded, and the in vitro cytocompatibility and in vivo biocompatibility of scaffolds was confirmed experimentally [267]. An interesting application of collagen is entubulation, hence the use of magnetically aligned type I collagen gel, achieved by exposing the forming collagen gel to a high strength magnetic field, as a filler for collagen tubes. This method was successful in small peripheral nerve lesions, improving nerve regeneration significantly in a $6 \mathrm{~mm}$ nerve gap in mice [268] and guiding neurite elongation and Schwann cell invasion in vitro [269] and in vivo [270].

\section{Conclusions and Future Perspectives}

Recently, smart materials have been of great interest for scientists and physicians, because of the many opportunities to use them as candidates for developing the next generation of biomedical devices, transient implants, and drug delivery vehicles. Considering smart scaffolds for tissue repair and regeneration, piezoelectric materials have recently been of particular interest as they can deliver electrical stimulus without an external power source. There is no doubt that the bioelectric signals produced by piezoelectric scaffolds can regenerate and repair the tissues by definite pathways similar to the natural processes occurring within the natural extracellular matrix (ECM). The combination of morphology together with the chemical, mechanical, and electrical properties of the scaffolds is crucial for the success in tissue regeneration. Electrical charges are particularly important in neural tissue engineering, in which electric pulses can stimulate neurite directional outgrowth to fill gaps in nervous tissue injuries. There is no doubt that the perspective of the broader application of piezoelectric scaffolds as smart materials for neural tissue regeneration is of great importance, allowing avoiding 
traditional (invasive) electrical stimulation. It was shown recently in in vitro conditions that the deformation of the piezoelectric scaffolds either by mechanical or ultrasound stimulation led to neurite extension and enhanced cell adhesion and proliferation. However, one should be aware that most of the up-to-date experiments using piezoelectric scaffolds were performed without such stimulation, which does not lead to piezoelectricity and resulting electrical charges. In such a case, the only charges that can be active from the cellular perspective are surface charges due to permanent polarization, as well as related to transient deformation caused by the contraction and protrusion of the attached cells. Nonetheless, it is crucial from the perspective of experiments with piezoelectric scaffolds to mimic the in vivo conditions with internal macro- and micro-deformations by in vitro conditions using mechanical (ultrasounds) agitation, allowing obtaining a real piezoelectric response. The next problem in the area of piezoelectric scaffolds is related to the non-biodegradability of the polymers exhibiting the highest piezoelectric coefficients, i.e., PVDF and its copolymers. Therefore, attention should be focused on biodegradable piezoelectric polymers like PHB or PLLA. An interesting alternative, which should be explored in the future, is related to the composite scaffolds containing an electro-conductive polymer like PANi in addition to a piezoelectric polymer. It was shown that the addition of an electro-conductive polymer to the piezoelectric matrix resulted in an increase in piezoelectricity. This kind of composite scaffold should be taken into account, when thinking about biodegradable piezoelectric polymers with originally relatively low piezoelectricity.

Author Contributions: Conceptualization, A.Z., P.S., and A.G.; validation, P.S. and A.G.; writing, original draft preparation, A.Z.; writing, review and editing, A.Z., P.S., and A.G.; visualization, A.Z., P.S., and A.G.; supervision, P.S., and A.G. All authors have read and agreed to the published version of the manuscript.

Funding: This research received no external funding.

Conflicts of Interest: The authors declare no conflict of interest.

\section{References}

1. Wolfenson, H.; Yang, B.; Sheetz, M.P. Steps in mechanotransduction pathways that control cell morphology. Annu. Rev. Physiol. 2019, 81, 585-605. [CrossRef] [PubMed]

2. Whalin, M.K.; Arora, S.S. Anatomy of the Brain and Spinal Cord. In Basic Sciences in Anesthesia; Farag, E., Argalious, M., Tetzlaff, J., Sharma, D., Eds.; Springer: New York, NY, USA, 2018; pp. 41-59.

3. Lis, A.; Szarek, D.; Laska, J. The outlook for the use of polymeric scaffolds in the reconstruction and the regeneration stimulation of traumatic brain injuries. Polim. Med. 2018, 43, 302-312.

4. Han, D.; Cheung, K.C. Biodegradable cell-seeded nanofiber scaffolds for neural repair. Polymers 2011, 3, 1684-1733. [CrossRef]

5. Balint, R.; Cassidy, N.J.; Cartmell, S.H. Conductive polymers: Towards a smart biomaterial for tissue engineering. Acta Biomat. 2014, 10, 2341-2353. [CrossRef]

6. Niemczyk, B.; Sajkiewicz, P.; Gradys, A. Injectable hydrogels as novel materials for central nervous system regeneration. J. Neural Eng. 2018, 15, 051002. [CrossRef]

7. Lis, A.; Szarek, D.; Laska, J. Biomaterials engineering strategies for spinal cord regeneration: State of the art. Polim. Med. 2013, 43, 59-80.

8. Taylor, C.A.; Bell, J.M.; Breiding, M.J.; Xu, L. Traumatic brain injury-Related emergency Department Visits, Hospitalizations, and Deaths-United States, 2007 and 2013. MMWR Surveill. Summ. 2017, 66, 1. [CrossRef]

9. Mathieu, S.; Manneville, J.B. Intracellular mechanics: Connecting rheology and mechanotransduction. COCEBI 2019, 56, 34-44. [CrossRef]

10. Delcroix, G.J.R.; Schiller, P.C.; Benoit, J.P.; MonteroMenei, C.N. Adult cell therapy for brain neuronal damages and the role of tissue engineering. Biomaterials 2010, 31, 2105-2120. [CrossRef]

11. Wang, S.; Hou, J.; Bei, J.; Zhao, Y. Tissue engineering and peripheral nerve regeneration (III)—Sciatic nerve regeneration with PDLLA nerve guide. Sci. China 2001, 44, 419-426. [CrossRef]

12. Adrian, H.; Mårten, K.; Salla, N.; Lasse, V. Biomarkers of Traumatic Brain Injury: Temporal Changes in Body Fluids. eNeuro 2016, 3, 0294-16. [CrossRef] [PubMed] 
13. Weidner, N.; Rudiger, R.; Tansey, K.E. Neurological Aspects of Spinal Cord Injury; Springer: Cham, Switzerland, 2017; Volume 1, pp. 3-17.

14. Zhang, L.; Sirivisoot, S.; Balasundaram, G.; Webster, T.J. Advanced Biomaterials: Fundamentals, Processing and Applications; Basu, B., Katti, D., Kumar, A., Eds.; John Wiley \& Sons, Inc.: Hoboken, NJ, USA, 2009.

15. Langlois, J.A.; Rutland-Brown, W.; Thomas, K.E. Traumatic Brain Injury in the United States: Emergency Department Visits, Hospitalizations, and Deaths, Centers for Disease Control and Prevention; National Center for Injury Prevention and Control: Atlanta, GA, USA, 2004.

16. Flax, J.D.; Aurora, S.; Yang, C. Engraftable human neural stem cells respond to developmental cues, replace neurons, and express foreign genes. Nature Biotechnol. 1998, 16, 1033-1438. [CrossRef] [PubMed]

17. Kordower, J.H.; Tuszynski, M.H. CNS Regeneration: Basic Science and Clinical Advances; Kordower, J.H., Tuszynski, M.H., Eds.; Academic: Cambridge, MA, USA, 1999; pp. 159-182.

18. Steel, E.M.; Sundararaghavan, H.G. Electrically Conductive Materials for Nerve Regeneration. In Neural Engineering; Springer: New York, NY, USA, 2016; pp. 145-179.

19. Zhao, P.; Gu, H.; Mi, H.; Rao, C.; Fu, J.; Turng, L.S. Fabrication of scaffolds in tissue engineering: A review. Front. Mech. Eng. 2018, 13, 107-119. [CrossRef]

20. Gao, S.; Tang, G.; Hua, D.; Xiong, R.; Han, J.; Jiang, S.; Huang, C. Stimuli-responsive bio-based polymeric systems and their applications. J. Mater. Chem. B 2019, 7, 709-729. [CrossRef]

21. Jalili-Firoozinezhad, S.; Mirakhori, F.; Baharvand, H. Nanotissue Engineering of Neural Cells. Stem Cell Nanoeng. 2015, 265, 265-283.

22. Nguyen, H.T.; Wei, C.; Chow, J.K.; Nguy, L.; Nguyen, H.K.; Schmidt, C.E. Electric field stimulation through a substrate influences Schwann cell and extracellular matrix structure. J. Neural Eng. 2013, 10, 046011. [CrossRef] [PubMed]

23. Chew, S.Y.; Wen, Y.; Dzenis, Y.; Leong, K.W. The role of electrospinning in the emerging field of nanomedicine. Curr. Pharm. Des. 2006, 12, 4751-4770. [CrossRef]

24. Murugan, R.; Ramakrishna, S. Nano-featured scaffolds for tissue engineering: A review of spinning methodologies. Tissue Eng. 2006, 12, 435-447. [CrossRef]

25. Venugopal, J.; Low, S.; Choon, A.T.; Ramakrishna, S. Interaction of cells and nanofiber scaffolds in tissue engineering. J. Biomed. Mater. Res. B 2008, 84, 34-48. [CrossRef]

26. Teo, W.E.; He, W.; Ramakrishna, S. Electrospun scaffold tailored for tissue-specific extracellular matrix. Biotechno. J. 2006, 1, 918-929. [CrossRef]

27. Barnes, C.P.; Sell, S.A.; Boland, E.D.; Simpson, D.G.; Bowlin, G.L. Nanofiber technology: Designing the next generation of tissue engineering scaffolds. Adv. Drug Deliv. Rev. 2007, 59, 1413-1433. [CrossRef]

28. Murugan, R.; Ramakrishna, S. Design strategies of tissue engineering scaffolds with controlled fiber orientation. Tissue Eng. 2007, 13, 1845-1866. [CrossRef] [PubMed]

29. Heydarkhan-Hagvall, S.; Schenke-Layland, K.; Dhanasopon, A.P.; Rofail, F.; Smith, H.; Wu, B.M.; Shemin, R.; Beygui, R.E.; MacLellan, W.R. Three-dimensional electrospun ECM-based hybrid scaffolds for cardiovascular tissue engineering. Biomaterials 2008, 29, 2907-2914. [CrossRef] [PubMed]

30. Li, W.J.; Mauck, J.A.; Cooper, X.; Yuan, R.S. Tuan Engineering controllable anisotropy in electrospun biodegradable nanofibrous scaffolds for musculoskeletal tissue engineering. J. Biomech. 2007, 40, 1686-1693. [CrossRef] [PubMed]

31. Li, W.J.; Tuli, R.; Huang, X.; Laquerriere, P.; Tuan, R.S. Multilineage differentiation of human mesenchymal stem cells in a three-dimensional nanofibrous scaffold. Biomaterials 2005, 26, 5158-5166. [CrossRef] [PubMed]

32. Yang, F.; Xu, C.Y.; Kotaki, M.; Wang, S.; Ramakrishna, S. Characterization of neural stem cells on electrospun poly(L-lactic acid) nanofibrous scaffold. J. Biomater. Sci. Polym. Ed. 2004, 15, 1483-1497. [CrossRef] [PubMed]

33. Ting, Y.; Gunawan, H.; Sugondo, A.; Chiu, C. A New Approach of Polyvinylidene Fluoride (PVDF) Poling Method for Higher Electric Response. Ferroelectrics 2013, 446, 28-38. [CrossRef]

34. Dang, Z.M.; Lin, Y.H.; Nan, C.W. Novel ferroelectric polymer composites with high dielectric constants. Adv. Mater. 2003, 15, 1625-1629. [CrossRef]

35. Bera, B.; Sarkar, M. Piezoelectricity in PVDF and PVDF Based Piezoelectric Nanogenerator: A Concept. Int. J. Appl. Phys. 2017, 9, 95-99. [CrossRef]

36. Damaraju, S.M.; Wu, S.; Jaffe, M.; Arinzeh, T.L. Structural changes in PVDF fibers due to electrospinning and its effect on biological function. Biomed. Mater. 2013, 8, 045007. [CrossRef] 
37. Defteralı, Ç.; Verdejo, R.; Majeed, S.; Boschetti-de-Fierro, A.; Méndez-Gómez, H.R.; Díaz-Guerra, E.; Vuluga, D. In vitro evaluation of biocompatibility of uncoated thermally reduced graphene and carbon nanotube-loaded PVDF membranes with adult neural stem cell-derived neurons and glia. Front. Bioeng. Biotechnol. 2016, 4, 94. [CrossRef] [PubMed]

38. Young, T.H.; Lin, U.H.; Lin, D.J.; Chang, H.H.; Cheng, L.P. Immobilization of L-lysine on microporous PVDF membranes for neuron culture. J. Biomater. Sci. Polym. 2009, 20, 703-720. [CrossRef] [PubMed]

39. Bar, H.N.; Bhat, M.R.; Murthy, C.R.L. Identification of failure modes in GFRP using PVDF sensors: ANN approach. Compos. Struct. 2004, 65, 231-237. [CrossRef]

40. Fu, Y.S.; Shih, Y.T.; Cheng, Y.C.; Min, M.Y. Transformation of human umbilical mesenchymal cells into neurons in vitro. J. Biomed. Sci. 2004, 11, 652-660. [CrossRef]

41. Ning, C.; Zhou, Z.; Tan, G.; Zhu, Y.; Mao, C. Electroactive polymers for tissue regeneration: Developments and perspectives. Prog. Polym. Sci. 2018, 81, 144-162. [CrossRef]

42. Moran, H.; Cancel, L.M.; Mayer, M.A.; Qazi, H.; Munn, L.L.; Tarbell, J.M. The cancer cell glycocalyx proteoglycan glypican-1 mediates interstitial flow mechanotransduction to enhance cell migration and metastasis. Biorheology 2019, 56, 151-161. [CrossRef]

43. Gargalionis, A.N.; Basdra, E.K.; Papavassiliou, A.G. Polycystins and Mechanotransduction in Human Disease. Int. J. Mol. Sci. 2019, 20, 2182. [CrossRef]

44. Maurer, M.; Lammerding, J. The driving force: Nuclear mechanotransduction in cellular function, fate, and disease. Annu. Rev. Biomed. Eng. 2019, 21, 443-468. [CrossRef]

45. Yamada, K.M.; Sixt, M. Mechanisms of 3D cell migration. Nat. Rev. Mol. 2019, 20, 738-752. [CrossRef]

46. Chang, W.; Gu, J.G. Impairment of tactile responses and Piezo channel mechanotransduction in mice following chronic vincristine treatment. Neurosci. Lett. 2019, 705, 14-19. [CrossRef]

47. Salvi, A.M.; DeMali, K.A. Mechanisms linking mechanotransduction and cell metabolism. COCEBI 2018, 54, 114-120. [CrossRef] [PubMed]

48. Pariy, I.O.; Ivanova, A.A.; Shvartsman, V.V.; Lupascu, D.C.; Sukhorukov, G.B.; Ludwig, T.; Surmenev, R.A. Piezoelectric Response in Hybrid Micropillar Arrays of Poly (Vinylidene Fluoride) and Reduced Graphene Oxide. Polymers 2019, 11, 1065. [CrossRef] [PubMed]

49. Ruan, L.; Yao, X.; Chang, Y.; Zhou, L.; Qin, G.; Zhang, X. Properties and Applications of the $\beta$ Phase Poly (vinylidene fluoride). Polymers 2018, 10, 228. [CrossRef] [PubMed]

50. Guilak, F.; Cohen, D.M.; Estes, B.T.; Gimble, J.M.; Liedtke, W.; Chen, C.S. Control of stem cell fate by physical interactions with the extracellular matrix. Cell Stem Cell 2009, 5, 17-26. [CrossRef] [PubMed]

51. Lee, M.R.; Kwon, K.W.; Jung, H.; Kim, H.N.; Suh, K.Y.; Kim, K.; Kim, K.S. Direct differentiation of human embryonic stem cells into selective neurons on nanoscale ridge/groove pattern arrays. Biomaterials 2010, 31, 4360-4366. [CrossRef] [PubMed]

52. McBeath, R.; Pirone, D.M.; Nelson, C.M.; Bhadriraju, K.; Chen, C.S. Cell shape, cytoskeletal tension, and RhoA regulate stem cell lineage commitment. Dev. Cell 2004, 6, 483-495. [CrossRef]

53. Verkhratsky, A.; Ho, M.S.; Parpura, V. Evolution of Neuroglia. In Neuroglia in Neurodegenerative Diseases; Springer: New York, NY, USA, 2019; pp. 15-44.

54. Georges, P.C.; Miller, W.J.; Meaney, D.F.; Sawyer, E.S.; Janmey, P.A. Matrices with compliance comparable to that of brain tissue select neuronal over glial growth in mixed cortical cultures. Biophys. J. 2006, 90, 3012-3018. [CrossRef]

55. Doetsch, F. A niche for adult neural stem cells. Curr. Opin. Genet. Dev. 2003, 13, 543-550. [CrossRef]

56. Alenghat, F.J.; Ingber, D.E. Mechanotransduction: All signals point to cytoskeleton, matrix, and integrins. Science's STKE: Signal transduction knowledge environment. Sci. Signal. 2002, 119, pe6. [CrossRef]

57. Kjellman, C.; Lidman, J.; Ljungström, K. Nilsson, Piezoelectric Sensor in a Living Organism for Fluid Pressure Measurement. U.S. Patent 6,886,411, 3 May 2005.

58. Wada, Y.; Hayakawa, R. Piezoelectricity and pyroelectricity of polymers. Jpn. J. Appl. Phys. 1976, $15,2041$. [CrossRef]

59. Parpaite, T.; Coste, B. Piezo channels. Curr. Biol. 2017, 27, R250-R252. [CrossRef] [PubMed]

60. Liu, Y.; Gao, J.; Peng, M.; Meng, H.; Ma, H.; Cai, P.; Si, G. A review on central nervous system effects of gastrodin. Front. Pharmacol. 2018, 9, 24. [CrossRef] [PubMed] 
61. Piccoli, A.; Rossettini, G.; Cecchetto, S.; Viceconti, A.; Ristori, D.; Turolla, A.; Testa, M. Effect of attentional focus instructions on motor learning and performance of patients with central nervous system and musculoskeletal disorders: A systematic review. J. Funct. Morphol. Kinesiol. 2018, 3, 40. [CrossRef]

62. Schulte, F.; Kunin-Batson, A.S.; Olson-Bullis, B.A.; Banerjee, P.; Hocking, M.C.; Janzen, L.; Krull, K.R. Social attainment in survivors of pediatric central nervous system tumors: A systematic review and meta-analysis from the Children's Oncology Group. J. Cancer Surviv. 2019, 13, 921-931. [CrossRef]

63. Saheb, N.; Mekid, S. Fiber-Embedded Metallic Materials: From Sensing towards Nervous Behavior. Materials 2015, 8, 7938-7961. [CrossRef]

64. Stavoe, A.K.; Holzbaur, E.L. Autophagy in Neurons. Annu. Rev. Cell Dev. Biol. 2019, 35, 477-500. [CrossRef]

65. Swenarchuk, L.E. Nerve, Muscle, and Synaptogenesis. Cells 2019, 8, 1448. [CrossRef]

66. Martí, D.; Brunel, N.; Ostojic, S. Correlations between synapses in pairs of neurons slow down dynamics in randomly connected neural networks. Phys. Rev. E 2018, 97, 062314. [CrossRef]

67. Van Driesche, S.J.; Martin, K.C. New frontiers in RNA transport and local translation in neurons. Dev. Neurobiol. 2018, 78, 331-339. [CrossRef]

68. Zhao, W.; Cui, W.; Xu, S.; Cheong, L.Z.; Wang, D.; Shen, C. Direct study of the electrical properties of PC12 cells and hippocampal neurons by EFM and KPFM. Nanoscale Adv. 2019, 1, 537-545. [CrossRef]

69. Averbeck, B.B.; Lee, D. Coding and transmission of information by neural ensembles. Trends Neurosci. 2004, 27, 225-230. [CrossRef]

70. Patel, N. Orientation of neurite growth by extracellar electric fields. J. Neurosci. 1982, 2, 483-496. [CrossRef]

71. Freeman, J.A.; Manis, P.B.; Snipes, G.J. Steady growth cone currents revealed by a novel circularly vibrating probe: A possible mechanism underlying neurite growth. J. Neurosci. 1985, 13, 257-283. [CrossRef] [PubMed]

72. Sisken, B.F.; Kanje, M.; Lundborg, G.; Herbst, E.; Kurtz, W. Stimulation of rat sciatic nerve regeneration with pulsed electromagnetic fields. Brain Res. 1989, 485, 309-316. [CrossRef]

73. Kimura, K.; Yanagida, Y.; Haruyama, T.; Kobatake, E.; Aizawa, M. Gene expression in the electrically stimulated differentiation of PC12 cells. J. Biotechnol. 1998, 63, 55-65. [CrossRef]

74. Kotwal, A.; Schmid, C.E. Electrical stimulation alters protein adsorption and nerve cell interactions with electrically conducting biomaterials. Biomaterials 2001, 22, 1055-1064. [CrossRef]

75. Ghasemi-Mobarakeh, L.; Prabhakaran, M.P.; Morshed, M.; Nasr-Esfahani, M.H.; Baharvand, H.; Kiani, S.; Ramakrishna, S. Application of conductive polymers, scaffolds and electrical stimulation for nerve tissue engineering. J. Tissue Eng. Regen. Med. 2011, 5, 17-35. [CrossRef]

76. Martin, R.M. Piezoelectricity. Phys. Rev. B 1972, 5, 1607. [CrossRef]

77. Shamos, M.H.; Lavine, L.S. Piezoelectricity as a fundamental property of biological tissues. Nature 1967, 213, 267-269. [CrossRef]

78. Telega, J.J.; Wojnar, R. Piezoelectric effects in biological tissues. J. Theor. Appl. Mech. 2002, 40, 723-759.

79. Fukada, E. Electrical phenomena in biorheology. Biorheology 1982, 19, 15-27. [CrossRef] [PubMed]

80. Athenstaedt, H. Pyroelectric and piezoelectric behaviour of human dental hard tissues. Arch. Oral Biol. 1971, 16, 495-501. [CrossRef]

81. De Rossi, D.; Domenici, D.; Pastacaldi, P. Piezoelectric Properties of Dry Human Skin. IEEE Trans. Electr. Insul. 1985, 21, 511-517. [CrossRef]

82. Ingber, D.E. The architecture of life. Sci. Am. 1998, 278, 48-57. [CrossRef]

83. Reyes-Gasga, J.; Galindo-Mentle, M.; Brès, E.; Vargas-Becerril, N.; Orozco, E.; Rodríguez-Gómez, A.; García-García, R. Detection of the piezoelectricity effect in nanocrystals from human teeth. J. Phys. Chem. Solids 2020, 136, 109140. [CrossRef]

84. Udovč, L.; Spreitzer, M.; Vukomanović, M. Towards hydrophilic piezoelectric poly-L-lactide films: Optimal processing, post-heat treatment and alkaline etching. Polym. J. 2019, 1-13. [CrossRef]

85. Hoop, M.; Chen, X.; Ferrari, A.; Fajer, M.; Gagik, G.; Theo, T.; Dimos, P.; Bradley, N.; Salvador, P. Ultrasound-mediated piezoelectric differentiation of neuron-like PC12 cells on PVDF membranes. Sci. Rep. 2017, 7, 4028. [CrossRef]

86. Ahn, A.C.; Grodzinsky, A.J. Relevance of collagen piezoelectricity to "Wolff's Law": A critical review. Med. Eng. Phys. 2009, 31, 733-741. [CrossRef]

87. Lang, S.B. Pyroelectric Effect in Bone and Tendon. Nature 1966, 212, 704-705. [CrossRef]

88. Anderson, J.C.; Eriksson, C. Electrical properties of wet collagen. Nature 1968, 218, 166-168. [CrossRef] 
89. Anderson, J.C.; Eriksson, C. Piezoelectric properties of dry and wet bone. Nature 1970, 227, 491-492. [CrossRef] [PubMed]

90. Fukada, E. Piezoelectricity in polymers and biological materials. Ultrasonics 1968, 6, 229-234. [CrossRef]

91. Furukawa, T. Piezoelectricity and pyroelectricity in polymers. IEEE Tran. Electr. Insul. 1989, 24, 375-394. [CrossRef]

92. Puppi, D.; Chiellini, F.; Piras, A.; Chiellini, E. Polymeric materials for bone and cartilage repair. Prog. Polym. Sci. 2010, 35, 403-440. [CrossRef]

93. Ribeiro, C.; Sencadas, V.; Correia, D.M.; Lanceros-Méndez, S. Piezoelectric polymers as biomaterials for tissue engineering applications. Colloids Surf. B Biointerfaces 2015, 136, 46-55. [CrossRef]

94. Fukada, E. History and recent progress in piezoelectric polymers. IEEE Trans. Ultrason. Ferroelectr. Freq. Control 2000, 47, 1277-1290. [CrossRef]

95. Zhong, Y.; Bellamkonda, R. V Biomaterials for the central nervous system. J. R. Soc. Interface 2008, 5, $957-975$. [CrossRef]

96. Jeznach, O.; Kołbuk, D.; Sajkiewicz, P. Injectable hydrogels and nanocomposite hydrogels for cartilage regeneration. J. Biomed. Mater. Res. A 2018, 106, 2762-2776. [CrossRef]

97. Brown, B.N.; Badylak, S.F. Extracellular matrix as an inductive scaffold for functional tissue reconstruction. Transl. Res. 2014, 163, 268-285. [CrossRef]

98. Ravichandran, R.; Astrand, C.; Patra, H.K.; Turner, A.P.; Chotteau, V.; Phopase, J. Intelligent ECM mimetic injectable scaffolds based on functional collagen building blocks for tissue engineering and biomedical applications. RSC Adv. 2017, 7, 21068-21078. [CrossRef]

99. Miguel, S.P.; Sequeira, R.S.; Moreira, A.F.; Cabral, C.C.; Mendonça, A.G.; Ferreira, P.; Correia, I.J. An overview of electrospun membranes loaded with bioactive molecules for improving the wound healing process. Eur. J. Pharm. Biopharm. 2019, 139, 1-22. [CrossRef] [PubMed]

100. Okamoto, M. The role of scaffolds in tissue engineering. In Handbook of Tissue Engineering Scaffolds; Elsevier: Amsterdam, The Netherlands, 2019; Volume 1, pp. 23-49.

101. Morgado, P.I.; Aguiar-Ricardo, A.; Correia, I.J. Asymmetric membranes as ideal wound dressings: An overview on production methods, structure, properties and performance relationship. J. Membr. Sci. 2015, 490, 139-151. [CrossRef]

102. Subramanian, A.; Krishnan, U.M.; Sethuraman, S. Development of biomaterial scaffold for nerve tissue engineering: Biomaterial mediated neural regeneration. J. Biomed. Sci. 2009, 16, 108. [CrossRef] [PubMed]

103. Shapiro, F. Overview of Deformities. In Pediatric Orthopedic Deformities; Springer: Cham, Switzerland, 2016; Volume 1, pp. 159-254.

104. Royo-Gascon, N.; Wininger, M.; Scheinbeim, J.I.; Firestein, B.L.; Craelius, W. Piezoelectric substrates promote neurite growth in rat spinal cord neurons. Ann. Biomed. Eng. 2013, 41, 112-122. [CrossRef] [PubMed]

105. Valentini, R.F.; Vargo, T.G.; Gardella, J.A., Jr.; Aebischer, P. Electrically charged polymeric substrates enhance nerve fibre outgrowth in vitro. Biomaterials 1992,13, 183-190. [CrossRef]

106. Aebischer, P.; Valentini, R.F.; Dario, P.; Domenici, C.; Galletti, P.M. Piezoelectric guidance channels enhance regeneration in the mouse sciatic nerve after axotomy. Brain Res. 1987, 436, 165-168. [CrossRef]

107. Delaviz, H.; Faghihi, A.; Delshad, A.A.; Hadi Bahadori, M.; Mohamadi, J.; Roozbehi, A. Repair of peripheral nerve defects using a polyvinylidene fluoride channel containing nerve growth factor and collagen gel in adult rats. Cell J. 2011, 13, 137-142.

108. Young, T.H.; Chang, H.H.; Lin, D.J.; Cheng, L.P. Surface modification of microporous PVDF membranes for neuron culture. J. Membr. Sci. 2010, 350, 32-41. [CrossRef]

109. Ariga, K.; Jia, X.; Song, J.; Hsieh, C.T.; Hsu, S.H. Materials Nanoarchitectonics as Cell Regulators. ChemNanoMat 2019, 5, 692-702. [CrossRef]

110. Ai, J.; Kiasat-Dolatabadi, A.; Ebrahimi-Barough, S.; Ai, A.; Lotfibakhshaiesh, N.; Norouzi-Javidan, A.; Aghayan, H.R. Polymeric scaffolds in neural tissue engineering: A review. Arch Neurosci. 2014, 1, 15-20. [CrossRef]

111. Abzan, N.; Kharaziha, M.; Labbaf, S. Development of three-dimensional piezoelectric polyvinylidene fluoride-graphene oxide scaffold by non-solvent induced phase separation method for nerve tissue engineering. Mater. Design 2019, 167, 107636. [CrossRef] 
112. Khorshidi, S.; Ansari, S.; Naghizadeh, Z.; Akbari, N.; Karkhaneh, A.; Haghighipour, N. Concurrent effects of piezoelectricity and hydrostatic pressure on chondrogenic differentiation of stem cells. Mater. Lett. 2019, 246, 71-75. [CrossRef]

113. Lee, Y.S.; Arinzeh, T.L. The influence of piezoelectric scaffolds on neural differentiation of human neural stem/progenitor cells. Tissue Eng. A 2012, 18, 2063-2072. [CrossRef] [PubMed]

114. Lee, Y.S.; Collins, G.; Arinzeh, T.L. Neurite extension of primary neurons on electrospun piezoelectric scaffolds. Acta Biomater. 2011, 7, 3877-3886. [CrossRef]

115. Genchi, G.G.; Sinibaldi, E.; Ceseracciu, L.; Labardi, M.; Marino, A.; Marras, S.; Ciofani, G. Ultrasound-activated piezoelectric $\mathrm{P}$ (VDF-TrFE)/boron nitride nanotube composite films promote differentiation of human SaOS-2 osteoblast-like cells. Nanomedicine 2018, 14, 2421-2432. [CrossRef]

116. Fine, E.G.; Valentini, R.F.; Bellamkonda, R.; Aebischer, P. Improved nerve regeneration through piezoelectric vinylidenefluoride-trifluoroethylene copolymer guidance channels. Biomaterials 1991, 12, 775-780. [CrossRef]

117. Wang, A.; Hu, M.; Zhou, L.; Qiang, X. Self-Powered Well-Aligned P (VDF-TrFE) Piezoelectric Nanofiber Nanogenerator for Modulating an Exact Electrical Stimulation and Enhancing the Proliferation of Preosteoblasts. Nanomaterials 2019, 9, 349. [CrossRef]

118. Collazos-Castro, J.E.; Polo, J.L.; Hernández-Labrado, G.R.; Padial-Cañete, V.; García-Rama, C. Bioelectrochemical control of neural cell development on conducting polymers. Biomaterials 2010, 31, 9244-9255. [CrossRef]

119. Ludwig, K.A.; Uram, J.D.; Yang, J.; Martin, D.C.; Kipke, D.R. Chronic neural recordings using silicon microelectrode arrays electrochemically deposited with a poly (3, 4-ethylenedioxythiophene)(PEDOT) film. J. Neural. Eng. 2006, 3, 59-70. [CrossRef]

120. Pires, F.; Ferreira, Q.; Rodrigues, C.A.; Morgado, J.; Ferreira, F.C. Neural stem cell differentiation by electrical stimulation using a cross-linked PEDOT substrate: Expanding the use of biocompatible conjugated conductive polymers for neural tissue engineering. Biochim. Biophys. Acta 2015, 1850, 1158-1168. [CrossRef]

121. Sebaa, M.; Nguyen, T.Y.; Dhillon, S.; Garcia, S.; Liu, H. The effects of poly (3, 4-ethylenedioxythiophene) coating on magnesium degradation and cytocompatibility with human embryonic stem cells for potential neural applications. J. Biomed. Mater. Res. A 2015, 103, 25-37. [CrossRef]

122. Du, L.; Li, T.; Jin, F.; Wang, Y.; Li, R.; Zheng, J.; Feng, Z.Q. Design of high conductive and piezoelectric poly (3, 4-ethylenedioxythiophene)/chitosan nanofibers for enhancing cellular electrical stimulation. J. Colloid Interface Sci. 2020, 559, 65-75. [CrossRef] [PubMed]

123. Evans, G.R.; Brandt, K.; Niederbichler, A.D.; Chauvin, P.; Hermann, S.; Bogle, M.; Patrick, C.W. Clinical long-term in vivo evaluation of poly (L-lactic acid) porous conduits for peripheral nerve regeneration. J. Biomater. Sci. Polym. 2000, 11, 869-878. [CrossRef] [PubMed]

124. Jia, L.; Prabhakaran, M.P.; Qin, X.; Ramakrishna, S. Stem cell differentiation on electrospun nanofibrous substrates for vascular tissue engineering. Mater. Sci. Eng. C 2013, 33, 4640-4650. [CrossRef] [PubMed]

125. Yang, F.; Murugan, R.; Ramakrishna, S.; Wang, X.; Ma, Y.X.; Wang, S. Fabrication of nano-structured porous PLLA scaffold intended for nerve tissue engineering. Biomaterials 2004, 25, 1891-1900. [CrossRef]

126. Yang, F.; Murugan, R.; Wang, S.; Ramakrishna, S. Electrospinning of nano/micro scale poly (L-lactic acid) aligned fibers and their potential in neural tissue engineering. Biomaterials 2005, 26, 2603-2610. [CrossRef]

127. Prabhakaran, M.P.; Venugopal, J.; Ramakrishna, S. Electrospun nanostructured scaffolds for bone tissue engineering. Acta Biomater. 2009, 5, 2884-2893. [CrossRef]

128. Prabhakaran, M.P.; Ghasemi-Mobarakeh, L.; Jin, G.; Ramakrishna, S. Electrospun conducting polymer nanofibers and electrical stimulation of nerve stem cells. J. Biosci. Bioeng. 2011, 112, 501-507. [CrossRef]

129. Jacob, J.; More, N.; Mounika, C.; Gondaliya, P.; Kalia, K.; Kapusetti, G. The Smart Piezoelectric Nanohybrid of Poly-(3-hydroxybutyrate-co-3-hydroxyvalerate) and Barium Titanate for Stimulated Cartilage Regeneration. ACS Appl. Bio Mater. 2019, 2, 4922-4931. [CrossRef]

130. De Guzman, R.C.; Loeb, J.A.; VandeVord, P.J. Electrospinning of matrigel to deposit a basal lamina-like nanofiber surface. J. Biomater. Sci. Polym. Ed. 2010, 21, 1081-1101. [CrossRef]

131. O'Shaughnessy, T.J.; Lin, H.J.; Ma, W. Functional synapse formation among rat cortical neurons grown on three-dimensional collagen gels. Neurosci. Lett. 2003, 340, 169-172. [CrossRef]

132. Shuai, C.; Liu, G.; Yang, Y.; Yang, W.; He, C.; Wang, G.; Peng, S. Functionalized BaTiO3 enhances piezoelectric effect towards cell response of bone scaffold. Colloids Surf. B. 2020, 185, 110587. [CrossRef] [PubMed] 
133. Mercadelli, E.; Sanson, A.; Galassi, C. Porous Piezoelectric Ceramics. In Piezoelectric Ceramics; Suaste-Gomez, E., Ed.; InTech: Rijeka, Croatia, 2010; pp. 111-129.

134. Wersing, W.; Lubitz, K.; Mohaupt, J. Dielectric, elastic and piezoelectric properties of porous PZT ceramics. Ferroelectrics 1986, 68, 77-97. [CrossRef]

135. Ringgaard, E.; Lautzenhiser, F.; Bierregaard, L.; Zawada, T.; Molz, E. Development of porous piezoceramics for medical and sensor applications. Materials 2015, 8, 8877-8889. [CrossRef] [PubMed]

136. Xue, C.; Hu, N.; Gu, Y.; Yang, Y.; Liu, Y.; Liu, J.; Ding, F.; Gu, X. Joint Use of a Chitosan/PLGA Scaffold and MSCs to Bridge an Extra Large Gap in Dog Sciatic Nerve. Neurorehabil. Neural Repair 2012, 26, 96-106. [CrossRef]

137. Carville, N.C.; Collins, L.; Manzo, M.; Gallo, K.; Lukasz, B.I.; McKayed, K.K.; Rodriguez, B.J. Biocompatibility of ferroelectric lithium niobate and the influence of polarization charge on osteoblast proliferation and function. J. Biomed. Mater. Res. A 2015, 103, 2540-2548. [CrossRef]

138. Furuya, K.; Morita, Y.; Tanaka, K.; Katayama, T.; Nakamachi, E. Acceleration of osteogenesis by using barium titanate piezoelectric ceramic as an implant material. In Proceedings of the International Society for Optics and Photonics, San Diego, CA, USA, 3-7 May 2011; Volume 7975, p. 79750 U.

139. Ball, J.P.; Mound, B.A.; Nino, J.C.; Allen, J.B. Biocompatible evaluation of barium titanate foamed ceramic structures for orthopedic applications. J. Biomed. Mater. Res. A 2014, 102, 2089-2095. [CrossRef]

140. Lopes, H.B.; Santos, T.D.S.; De Oliveira, F.S.; Freitas, G.P.; De Almeida, A.L.; Gimenes, R.; Beloti, M.M. Poly (vinylidene-trifluoroethylene)/barium titanate composite for in vivo support of bone formation. J. Biomater. Appl. 2014, 29, 104-112. [CrossRef]

141. Zhang, X.; Zhang, C.; Lin, Y.; Hu, P.; Shen, Y.; Wang, K.; Liu, Y. Nanocomposite membranes enhance bone regeneration through restoring physiological electric microenvironment. ACS Nano 2016, 10, 7279-7286. [CrossRef]

142. Roberts, S. Dielectric and piezoelectric properties of barium titanate. Phys. Rev. 1947, 71, 890. [CrossRef]

143. Baxter, F.R.; Bowen, C.R.; Turner, I.G.; Dent, A.C. Electrically active bioceramics: A review of interfacial responses. Ann. Biomed. Eng. 2010, 38, 2079-2092. [CrossRef] [PubMed]

144. Ciofani, G.; Ricotti, L.; Canale, C.; D'Alessandro, D.; Berrettini, S.; Mazzolai, B.; Mattoli, V. Effects of barium titanate nanoparticles on proliferation and differentiation of rat mesenchymal stem cells. Colloids Surf. B Biointerfaces 2013, 102, 312-320. [CrossRef]

145. Ciofani, G.; Ricotti, L.; Mattoli, V. Preparation, characterization and in vitro testing of poly (lactic-co-glycolic) acid/barium titanate nanoparticle composites for enhanced cellular proliferation. Biomed. Microdevices 2011, 13, 255-266. [CrossRef] [PubMed]

146. Ivanova, O.; Williams, C.; Campbell, T. Additive manufacturing (AM) and nanotechnology: Promises and challenges. Rapid Prototyp. J. 2013, 19, 353-364. [CrossRef]

147. Jacob, J.; More, N.; Kalia, K.; Kapusetti, G. Piezoelectric smart biomaterials for bone and cartilage tissue engineering. Inflamm. Regen. 2018, 38, 2. [CrossRef]

148. Matassi, F.; Nistri, L.; Paez, D.C.; Innocenti, M. New biomaterials for bone regeneration. Clin. Cases Miner. Bone Metab. 2011, 8, 21.

149. Ahmad, P.; Khandaker, M.U.; Khan, Z.R.; Amin, Y.M. Synthesis of boron nitride nanotubes via chemical vapour deposition: A comprehensive review. Mater. Sci. Eng. R. 2010, 70, 92-111. [CrossRef]

150. Lahiri, D.; Rouzaud, F.; Richard, T.; Keshri, A.K.; Bakshi, S.R.; Kos, L.; Agarwal, A. Boron nitride nanotube reinforced polylactide-polycaprolactone copolymer composite: Mechanical properties and cytocompatibility with osteoblasts and macrophages in vitro. Acta Biomater. 2010, 6, 3524-3533. [CrossRef]

151. Lahiri, D.; Singh, V.; Benaduce, A.P.; Seal, S.; Kos, L.; Agarwal, A. Boron nitride nanotube reinforced hydroxyapatite composite: Mechanical and tribological performance and in-vitro biocompatibility to osteoblasts. J. Mech. Behav. Biomed. 2011, 4, 44-56. [CrossRef]

152. Li, X.; Zhi, C.; Hanagata, N.; Yamaguchi, M.; Bando, Y.; Golberg, D. Boron nitride nanotubes functionalized with mesoporous silica for intracellular delivery of chemotherapy drugs. Chem. Commun. 2013, 49, 7337-7339. [CrossRef]

153. Ciofani, G.; Danti, S.; Genchi, G.G.; Mazzolai, B.; Mattoli, V. Boron nitride nanotubes: Biocompatibility and potential spill-over in nanomedicine. Small 2013, 9, 1672-1685. [CrossRef] [PubMed] 
154. Li, X.; Hanagata, N.; Wang, X.; Yamaguchi, M.; Yi, W.; Bando, Y.; Golberg, D. Multimodal luminescent-magnetic boron nitride nanotubes@ NaGdF 4: Eu structures for cancer therapy. Chem. Commun. 2014, 50, 4371-4374. [CrossRef]

155. Weng, Q.; Wang, B.; Wang, X.; Hanagata, N.; Li, X.; Liu, D.; Golberg, D. Highly water-soluble, porous, and biocompatible boron nitrides for anticancer drug delivery. ACS Nano 2014, 8, 6123-6130. [CrossRef] [PubMed]

156. Wang, J.; Lee, C.H.; Yap, Y.K. Recent advancements in boron nitride nanotubes. Nanoscale 2010, 2, $2028-2034$. [CrossRef] [PubMed]

157. Ciofani, G.; Raffa, V.; Menciassi, A.; Cuschieri, A. Boron nitride nanotubes: An innovative tool for nanomedicine. Nano Today 2009, 4, 8-10. [CrossRef]

158. Rasmussen, J.W.; Martinez, E.; Louka, P.; Wingett, D.G. Zinc oxide nanoparticles for selective destruction of tumor cells and potential for drug delivery applications. Expert Opin. Drug Deliv. 2010, 7, 1063-1077. [CrossRef]

159. Goel, S.; Kumar, B. A review on piezo-/ferro-electric properties of morphologically diverse ZnO nanostructures. J. Alloys Compd. 2019, 816, 152491. [CrossRef]

160. Yin, Y.; Lin, Q.; Sun, H.; Chen, D.; Wu, Q.; Chen, X.; Li, S. Cytotoxic effects of ZnO hierarchical architectures on RSC96 Schwann cells. Res. Lett. 2012, 7, 439. [CrossRef]

161. Safaei, M.; Sodano, H.A.; Anton, S.R. A review of energy harvesting using piezoelectric materials: State-of-the-art a decade later (2008-2018). Smart Mater. Struct. 2019, 28, 113001. [CrossRef]

162. Ribeiro, C.; Correia, D.M.; Ribeiro, S.; Sencadas, V.; Botelho, G.; Lanceros-Méndez, S. Piezoelectric poly (vinylidene fluoride) microstructure and poling state in active tissue engineering. Eng. Life Sci. 2015, 15, 351-356. [CrossRef]

163. Aguilar, M.R.; San Román, J. Introduction to smart polymers and their applications. In Smart Polymers and Their Applications; Woodhead Publishing: Sawston, UK, 2019; pp. 1-11.

164. Piskin, E. Biodegradable polymers as biomaterials. J. Biomater. Sci. Polym. Ed. 1995, 6, 775-795. [CrossRef] [PubMed]

165. Sajkiewicz, P. Crystallization behaviour of poly(vinylidene fluoride). Eur. Polym. J. 1999, 35, 1581-1590. [CrossRef]

166. Gradys, A.; Sajkiewicz, P.; Adamovsky, S.; Minakov, A.A.; Schick, C. Crystallization of poly(vinylidene fluoride) during ultra-fast cooling. Thermochim. Acta 2007, 461, 153-157. [CrossRef]

167. Esterly, D.M.; Love, B.J. Phase transformation to $\beta$-poly (vinylidene fluoride) by milling. J. Polym. Sci. B Polym. Phys. 2004, 42, 91-97. [CrossRef]

168. Cozza, E.S.; Monticelli, O.; Marsano, E.; Cebe, S. On the Electrospinning of PVDF: Influence of the Experimental Conditions on the Nanofiber Properties. Polym. Int. 2013, 62, 41-48. [CrossRef]

169. Yu, L.; Cebe, P. Crystal polymorphism in electrospun composite nanofibers of poly (vinylidene fluoride) with nanoclay. Polymer 2009, 50, 2133-2141. [CrossRef]

170. El Mohajir, B.E.; Heymans, N. Changes in structural and mechanical behaviour of PVDF with processing and thermomechanical treatments. 1. Change in structure. Polymer 2001, 42, 5661-5667. [CrossRef]

171. Imamura, R.; Silva, A.B.; Gregorio, R., Jr. $\gamma \rightarrow \beta$ Phase transformation induced in poly (vinylidene fluoride) by stretching. J. Appl. Polym. Sci. 2008, 110, 3242-3246. [CrossRef]

172. Wang, J.; Li, H.; Liu, J.; Duan, Y.; Jiang, S.; Yan, Y. On the $\alpha \rightarrow \beta$ Transition of Carbon Coated Highly Oriented PVDF Ultrathin Film Induced by Melt Recrystallization. J. Am. Chem. Soc. 2003, 125, 1496-1497. [CrossRef]

173. Kaura, T.; Nath, R.; Perlman, M.M. Simultaneous stretching and corona poling of PVDF films. J. Phys. D: Appl. Phys. 1991, 24, 1848. [CrossRef]

174. Ramanathan, A.K.; Headings, L.M.; Dapino, M.J. Design optimization of flexible piezoelectric PVDF unimorphs for surface pressure transducer applications. In Smart Structures and NDE for Energy Systems and Industry 4.0; International Society for Optics and Photonics: Bellingham, WA, USA, 2019; Volume 10973, p. 1097307.

175. Ellingford, C.; Smith, H.; Yan, X.; Bowen, C.; Figiel, Ł.; McNally, T.; Wan, C. Electrical dual-percolation in MWCNTs/SBS/PVDF based thermoplastic elastomer (TPE) composites and the effect of mechanical stretching. Eur. Polym. J. 2019, 112, 504-514. [CrossRef]

176. Zhang, S.; Jia, Z.; Liu, T.; Wei, G.; Su, Z. Electrospinning Nanoparticles-Based Materials Interfaces for Sensor Applications. Sensors 2019, 19, 3977. [CrossRef] [PubMed] 
177. Li, Y.; Liao, C.; Tjong, S.C. Electrospun Polyvinylidene Fluoride-Based Fibrous Scaffolds with Piezoelectric Characteristics for Bone and Neural Tissue Engineering. Nanomaterials 2019, 9, 952. [CrossRef] [PubMed]

178. Yu, L.; Zhou, P.; Wu, D.; Wang, L.; Lin, L.; Sun, D. Shoepad nanogenerator based on electrospun PVDF nanofibers. Microsyst. Technol. 2019, 25, 3151-3156. [CrossRef]

179. Ribeiro, C.; Costa, C.M.; Correia, D.M.; Nunes-Pereira, J.; Oliveira, J.; Martins, P.; Lanceros-Méndez, S. Electroactive poly (vinylidene fluoride)-based structures for advanced applications. Nat. Protoc. 2018, $13,681$. [CrossRef] [PubMed]

180. Fortunato, M.; Cavallini, D.; De Bellis, G.; Marra, F.; Tamburrano, A.; Sarto, F.; Sarto, M.S. Phase Inversion in PVDF Films with Enhanced Piezoresponse Through Spin-Coating and Quenching. Polymers 2019, 11, 1096. [CrossRef]

181. Liu, Z.H.; Pan, C.T.; Lin, L.W.; Huang, J.C.; Ou, Z.Y. Direct-write PVDF nonwoven fiber fabric energy harvesters via the hollow cylindrical near-field electrospinning process. Smart Mater. Struct. 2013, 23, 025003. [CrossRef]

182. Zaarour, B.; Zhu, L.; Jin, X. Controlling the surface structure, mechanical properties, crystallinity, and piezoelectric properties of electrospun PVDF nanofibers by maneuvering molecular weight. Soft Mater. 2019, 17, 181-189. [CrossRef]

183. Singh, R.K.; Lye, S.W.; Miao, J. PVDF Nanofiber Sensor for Vibration Measurement in a String. Sensors 2019, 19, 3739. [CrossRef]

184. Khalifa, M.; Janakiraman, S.; Ghosh, S.; Venimadhav, A.; Anandhan, S. PVDF/halloysite nanocomposite-based non-wovens as gel polymer electrolyte for high safety lithium ion battery. Polym. Compos. 2019, 40, 2320-2334. [CrossRef]

185. Liang, S.; Kang, Y.; Tiraferri, A.; Giannelis, E.P.; Huang, X.; Elimelech, M. Highly hydrophilic polyvinylidene fluoride (PVDF) ultrafiltration membranes via postfabrication grafting of surface-tailored silica nanoparticles. ACS Appl. Mater. Interfaces 2013, 5, 6694-6703. [CrossRef] [PubMed]

186. Mandal, D.; Henkel, K.; Schmeißer, D. The electroactive $\beta$-phase formation in poly (vinylidene fluoride) by gold nanoparticles doping. Materials Lett. 2012, 73, 123-125. [CrossRef]

187. Li, J.H.; Shao, X.S.; Zhou, Q.; Li, M.Z.; Zhang, Q.Q. The double effects of silver nanoparticles on the PVDF membrane: Surface hydrophilicity and antifouling performance. App. Surf. Sci. 2013, 265, 663-670. [CrossRef]

188. Liang, S.; Xiao, K.; Mo, Y.; Huang, X. A novel ZnO nanoparticle blended polyvinylidene fluoride membrane for anti-irreversible fouling. J. Membr. Sci. 2012, 394, 184-192. [CrossRef]

189. Teow, Y.H.; Ahmad, A.L.; Lim, J.K.; Ooi, B.S. Preparation and characterization of PVDF/TiO2 mixed matrix membrane via in situ colloidal precipitation method. Desalination 2012, 295, 61-69. [CrossRef]

190. Zhang, J.; Xu, Z.; Mai, W.; Min, C.; Zhou, B.; Shan, M.; Qian, X. Improved hydrophilicity, permeability, antifouling and mechanical performance of PVDF composite ultrafiltration membranes tailored by oxidized low-dimensional carbon nanomaterials. J. Mater. Chem. A 2013, 1, 3101-3111. [CrossRef]

191. Song, H.; Shao, J.; He, Y.; Liu, B.; Zhong, X. Natural organic matter removal and flux decline with PEG-TiO2-doped PVDF membranes by integration of ultrafiltration with photocatalysis. J. Membr. Sci. 2012, 405, 48-56. [CrossRef]

192. Li, N.; Xiao, C.; An, S.; Hu, X. Preparation and properties of PVDF/PVA hollow fiber membranes. Desalination 2010, 250, 530-537. [CrossRef]

193. Gayen, A.L.; Mondal, D.; Roy, D.; Bandyopadhyay, P.; Manna, S.; Basu, R.; Nandy, P. Improvisation of electrical properties of PVDF-HFP: Use of novel metallic nanoparticles. J. Mater. Sci.: Mater. 2017, 28, 14798-14808. [CrossRef]

194. Jaleh, B.; Sodagar, S.; Momeni, A.; Jabbari, A. Nanodiamond particles/PVDF nanocomposite flexible films: Thermal, mechanical and physical properties. Mater. Res. Express 2016, 3, 085028. [CrossRef]

195. Fraczek-Szczypta, A. Carbon nanomaterials for nerve tissue stimulation and regeneration. Mater. Sci. Eng. C 2014, 34, 35-49. [CrossRef]

196. Tsonos, C.; Pandis, C.; Soin, N.; Sakellari, D.; Myrovali, E.; Kripotou, S.; Siores, E. Multifunctional nanocomposites of poly (vinylidene fluoride) reinforced by carbon nanotubes and magnetite nanoparticles. Express Polym. Lett. 2015, 9. [CrossRef]

197. Lorber, B.; Hsiao, W.K.; Hutchings, I.M.; Martin, K.R. Adult rat retinal ganglion cells and glia can be printed by piezoelectric inkjet printing. Biofabrication 2013, 6, 015001. [CrossRef] [PubMed] 
198. Inaoka, T.; Shintaku, H.; Nakagawa, T.; Kawano, S.; Ogita, H.; Sakamoto, T.; Ito, J. Piezoelectric materials mimic the function of the cochlear sensory epithelium. Proc. Natl. Acad. Sci. USA 2011, 108, 18390-18395. [CrossRef] [PubMed]

199. Gao, Y.; Wang, Z.L. Electrostatic potential in a bent piezoelectric nanowire. The fundamental theory of nanogenerator and nanopiezotronics. Nano Lett. 2007, 7, 2499-2505. [CrossRef] [PubMed]

200. Walsh, J.F.; Manwaring, M.E.; Tresco, P.A. Directional neurite outgrowth is enhanced by engineered meningeal cell-coated substrates. Tissue Eng. 2005, 11, 1085-1094. [CrossRef] [PubMed]

201. Asano, T.; Kubo, T.; Nishikitani, Y. Electrochemical properties of dye-sensitized solar cells fabricated with PVDF-type polymeric solid electrolytes. J. Photochem. Photobiol. 2004, 164, 111-115. [CrossRef]

202. Marino, A.; Arai, S.; Hou, Y.; Sinibaldi, E.; Pellegrino, M.; Chang, B.; Mazzolai, V.; Mattoli Suzuki, M.; Ciofani, G. Piezoelectric nanoparticle-assisted wireless neuronal stimulation. ACS Nano 2015, 9, 7678-7689. [CrossRef]

203. Genchi, G.G.; Ceseracciu, L.; Marino, A.; Labardi, M.; Marras, S.; Pignatelli, F.; Bruschini, L.; Mattoli, V.; Ciofani, G. P(VDF-TrFE)/BaTiO3 nanoparticle composite films mediate piezoelectric stimulation and promote differentiation of SH-SY5Y neuroblastoma cells. Adv. Healthc. Mater. 2016, 5, 1808-1820. [CrossRef]

204. Weber, N.; Lee, Y.S.; Shanmugasundaram, S.; Jaffe, M.; Arinzeh, T.L. Characterization and in vitro cytocompatibility of piezoelectric electrospun scaffolds. Acta Biomater. 2010, 6, 3550-3556. [CrossRef]

205. De Ruiter, G.C.; Malessy, M.J.; Yaszemski, M.J.; Windebank, A.J.; Spinner, R.J. Designing ideal conduits for peripheral nerve repair. Neurosurg. Focus. 2009, 26, E5. [CrossRef] [PubMed]

206. Ichihara, S.; Inada, Y.; Nakamura, T. Artificial nerve tubes and their application for repair of peripheral nerve injury: An update of current concepts. Injury 2008, 39, 29-39. [CrossRef] [PubMed]

207. Ji, Y.; Jin, R.; Zhang, X.; Bouchilaoun, R.; Fan, J.; Zhao, R.; Yang, H. Electric polarizations in PVDF-TrFE nanorods under lateral nanoshaping. Int. J. Appl. 2019, 126, 174108. [CrossRef]

208. Wan, C.; Bowen, C.R. Multiscale-structuring of polyvinylidene fluoride for energy harvesting: The impact of molecular-, micro- and macro-structure. J. Mater. Chem. A 2017, 5, 3091-3128. [CrossRef]

209. Sun, F.C.; Dongare, A.M.; Asandei, A.D.; Alpay, S.P.; Nakhmanson, S. Temperature dependent structural, elastic, and polar properties of ferroelectric polyvinylidene fluoride (PVDF) and trifluoroethylene (TrFE). copolymers. J. Mater. Chem. C 2015, 3, 8389-8396. [CrossRef]

210. Belkas, J.S.; Shoichet, M.S.; Midha, R. Peripheral nerve regeneration through guidance tubes. Neurol. Res. 2004, 26, 151-160. [CrossRef]

211. Boni, R.; Ali, A.; Shavandi, A.; Clarkson, A.N. Current and novel polymeric biomaterials for neural tissue engineering. J Biomed. Sci. 2018, 25, 90. [CrossRef]

212. Fine, E.G.; Valentini, R.F.; Bellamkonda, R.; Aebischer, P. Influence of surface texture of polymeric sheets throught piezoelectric vinylidenefluoride-trifluoroethylene copolymer guidance channels. Biomaterials 1991, 12, 259-263. [CrossRef]

213. Martins, P.M.; Ribeiro, S.; Ribeiro, C.; Sencadas, V.; Gomes, A.C.; Gama, F.M.; Lanceros-Méndez, S. Effect of poling state and morphology of piezoelectric poly(vinylidene fluoride) membranes for skeletal muscle tissue engineering. RSC Adv. 2013, 3, 17938-17944. [CrossRef]

214. Ke, S.; Huang, H.; Ren, L.; Wang, Y. Nearly constant dielectric loss behavior in poly (3-hydroxybutyrate-co-3-hydroxyvalerate) biodegradable polyester. J. Appl. Phys. 2009. [CrossRef]

215. Numata, K.; Abe, H.; Doi, Y. Enzymatic processes for biodegradation of poly (hydroxyalkanoate) s crystals. Can. J. Chem. 2008, 86, 471-483. [CrossRef]

216. Willerth, S.M.; Sakiyama-Elbert, S.E. Approaches to neural tissue engineering using scaffolds for drug delivery. Adv. Drug Deliv. Rev. 2007, 59, 325-338. [CrossRef] [PubMed]

217. Wu, Q.; Wang, Y.; Chen, G.Q. Medical application of microbial biopolyesters polyhydroxyalkanoates. Artif. Cells Blood Substit. Immobil. Biotechnol. 2009, 37, 1-12. [CrossRef] [PubMed]

218. Misra, S.K.; Valappil, S.P.; Roy, I.; Boccaccini, A.R. Polyhydroxyalkanoate (PHA)/inorganic phase composites for tissue engineering applications. Biomacromolecules 2006, 7, 2249-2258. [CrossRef]

219. Prabhakaran, M.P.; Vatankhah, E.; Ramakrishna, S. Electrospun aligned PHBV/collagen nanofibers as substrates for nerve tissue engineering. Biotechnol Bioeng. 2013, 110, 2775-2784. [CrossRef]

220. Rahman, M.S.; Tsuchiya, T. Enhancement of chondrogenic differentiation of human articular chondrocytes by biodegradable polymers. Tissue Eng. 2001, 7, 781-790. [CrossRef] 
221. Chen, W.; Tong, Y.W. PHBV microspheres as neural tissue engineering scaffold support neuronal cell growth and axon-dendrite polarization. Acta Biomater. 2012, 8, 540-548. [CrossRef]

222. Rivera-Briso, A.L.; Serrano-Aroca, A. Poly(3-Hydroxybutyrate-co-3-Hydroxyvalerate): Enhancement Strategies for Advanced Applications. Polymers 2018, 10, 732. [CrossRef]

223. Sencadas, V.; Ribeiro, C.; Heredia, A.; Bdikin, I.K.; Kholkin, A.L.; Lanceros-Méndez, S. Local piezoelectric activity of single poly (L-lactic acid)(PLLA) microfibers. Appl. Phys. A 2012, 109, 51-55. [CrossRef]

224. Jin, L.; Feng, Z.Q.; Zhu, M.L.; Wang, T.; Leach, M.K.; Jiang, Q. A novel fluffy conductive polypyrrole nano-layer coated PLLA fibrous scaffold for nerve tissue engineering. J. Biomed. Nanotechnol. 2012, 8, 779-785. [CrossRef]

225. Zhang, K.; Zheng, H.; Liang, S.; Gao, C. Aligned PLLA nanofibrous scaffolds coated with graphene oxide for promoting neural cell growth. Acta Biomater. 2016, 37, 131-142. [CrossRef] [PubMed]

226. Zuidema, J.M.; Provenza, C.; Caliendo, T.; Dutz, S.; Gilbert, R.J. Magnetic NGF-releasing PLLA/iron oxide nanoparticles direct extending neurites and preferentially guide neurites along aligned electrospun microfibers. ACS Chem. Neurosci. 2015, 6, 1781-1788. [CrossRef] [PubMed]

227. Venugopal, J.; Zhang, Y.Z.; Ramakrishna, S. Electrospun nanofibres: Biomedical applications. Proceedings of the institution of mechanical engineers. N J. Nanoeng. Nanosyst. 2004, 218, 35-45.

228. Philipp, B.; Bock, W.; Schierbaum, F. Application of polysaccharides and their derivatives as supporting materials and auxiliary substances in medicine and nutrition. J. Polym. Sci. Polym. Symp. 1979, 66, 83-100. [CrossRef]

229. Franz, G. Polysaccharides in pharmacy. Adv. Polym. Sci. 1986, 76, 1-30.

230. Miyamoto, T.; Takahashi, S.I.; Ito, H.; Inagaki, H.; Noishiki, Y. Tissue biocompatibility of cellulose and its derivatives. J. Biomed. Mater. Res. 1989, 23, 125-133. [CrossRef]

231. Ikada, Y. Biomedical applications of cellulose membranes. In Cellulose: Structural and Functional Aspects; Kennedy, J.F., Phillips, G.O., Williams, P.A., Eds.; Ellis Horwood: Chichester, UK, 1989; pp. 447-455.

232. Barbié, C.; Chauveaux, D.; Barthe, X.; Baquey, C.; Poustis, J. Biological behaviour of cellulosic materials after bone implantation: Preliminary results. Clin. Mater. 1990, 5, 251-258. [CrossRef]

233. Gross, U.; Muller-Mai, C.; Voigt, C. The tissue response on cellulose cylinders after implantation in the distal femur of rabbits. In Proceedings of the Fourth World Biomaterials Congress, Berlin, Germany, 19-24 May 1992; p. 192.

234. Märtson, M.; Viljanto, J.; Hurme, T.; Saukko, P. Biocompatibility of cellulose sponge with bone. Eur. Surg. Res. 1998, 30, 426-432. [CrossRef]

235. Bhatnagar, A.; Sain, M. Processing of cellulose nanofiber-reinforced composites. J. Reinf. Plast. Comp. 2005, 24, 1259-1268. [CrossRef]

236. Fricain, J.C.; Granja, P.L.; Barbosa, M.A.; De Jéso, B.; Barthe, N.; Baquey, C. Cellulose phosphates as biomaterials. In vivo biocompatibility studies. Biomaterials 2002, 23, 971-980. [CrossRef]

237. Svensson, A.; Nicklasson, E.; Harrah, T.; Panilaitis, B.; Kaplan, D.L.; Brittberg, M.; Gatenholm, P. Bacterial cellulose as a potential scaffold for tissue engineering of cartilage. Biomaterials 2005, 26, 419-431. [CrossRef] [PubMed]

238. Märtson, M.; Viljanto, J.; Laippala, P.; Saukko, P. Connective tissue formation in subcutaneous cellulose sponge implants in the rat. Eur. Surg. Res. 1998, 30, 419-425. [CrossRef] [PubMed]

239. Fundueanu, G.; Constantin, M.; Esposito, E.; Cortesi, R.; Nastruzzi, C.; Menegatti, E. Cellulose acetate butyrate microcapsules containing dextran ion-exchange resins as self-propelled drug release system. Biomaterials 2005, 26, 4337-4347. [CrossRef] [PubMed]

240. Entcheva, E.; Bien, H.; Yin, L.; Chung, C.Y.; Farrell, M.; Kostov, Y. Functional cardiac cell constructs on cellulose-based scaffolding. Biomaterials 2004, 25, 5753-5762. [CrossRef]

241. Tate, M.C.; Shear, D.A.; Hoffman, S.W.; Stein, D.G.; LaPlaca, M.C. Biocompatibility of methylcellulose-based constructs designed for intracerebral gelation following experimental traumatic brain injury. Biomaterials 2001, 22, 1113-1123. [CrossRef]

242. Hoseini, S.M.; Khosravi-Darani, K.; Mozafari, M.R. Nutritional and medical applications of spirulina microalgae. Mini Rev. Med. Chem. 2013, 13, 1231-1237. [CrossRef]

243. Granja, P.L.; Barbosa, M.A.; Pouységu, L.; De Jéso, B.; Rouais, F.; Baquey, C. Cellulose phosphates as biomaterials. Mineralization of chemically modified regenerated cellulose hydrogels. J. Mater. Sci. 2001, 36, 2163-2172. [CrossRef] 
244. Naseri-Nosar, M.; Salehi, M.; Hojjati-Emami, S. Cellulose acetate/poly lactic acid coaxial wet-electrospun scaffold containing citalopram-loaded gelatin nanocarriers for neural tissue engineering applications. Int. J. Biol. Macromol. 2017, 103, 701-708. [CrossRef]

245. Wang, S.; Sun, C.; Guan, S.; Li, W.; Xu, J.; Ge, D.; Ma, X. Chitosan/gelatin porous scaffolds assembled with conductive poly (3, 4-ethylenedioxythiophene) nanoparticles for neural tissue engineering. J. Mat. Chem. B 2017, 5, 4774-4788. [CrossRef]

246. Koide, S.S. Chitin-chitosan: Properties, benefits and risks. Nutr. Res. 1998, 18, 1091-1101. [CrossRef]

247. Rinaudo, M. Chitin and chitosan: Properties and applications. Prog. Polym. Sci. 2006, 31, 603-632. [CrossRef]

248. Madihally, S.V.; Matthew, H.W. Porous chitosan scaffolds for tissue engineering. Biomaterials 1999, 20, 1133-1142. [CrossRef]

249. Ohkawa, K.; Cha, D.; Kim, H.; Nishida, A.; Yamamoto, H. Electrospinning of chitosan. Macromol. Rapid Commun. 2004, 25, 1600-1605. [CrossRef]

250. Izzo, D.; Palazzo, B.; Scalera, F.; Gullotta, F.; Lapesa, V.; Scialla, S.; Gervaso, F. Chitosan scaffolds for cartilage regeneration: Influence of different ionic crosslinkers on biomaterial properties. Int. J. Polym. Mater. 2019, 68, 936-945. [CrossRef]

251. Maged, A.; Abdelkhalek, A.A.; Mahmoud, A.A.; Salah, S.; Ammar, M.M.; Ghorab, M.M. Mesenchymal stem cells associated with chitosan scaffolds loaded with rosuvastatin to improve wound healing. Eur. J. Pharm. Sci. 2019, 127, 185-198. [CrossRef]

252. Xue, Y.; Wu, M.; Liu, Z.; Song, J.; Luo, S.; Li, H.; Chen, F. In vitro and in vivo evaluation of chitosan scaffolds combined with simvastatin-loaded nanoparticles for guided bone regeneration. J. Mater. Sci. Mater. Med. 2019, 30, 47. [CrossRef]

253. Skop, N.B.; Calderon, F.; Levison, S.W.; Gandhi, C.D.; Cho, C.H. Heparin crosslinked chitosan microspheres for the delivery of neural stem cells and growth factors for central nervous system repair. Acta Biomater. 2013, 9, 6834-6843. [CrossRef]

254. Elnaggar, Y.S.R.; Etman, S.M.; Abdelmonsif, D.A. Intranasal Piperine-Loaded Chitosan Nanoparticles as Brain-Targeted Therapy in Alzheimer's Disease: Optimization, Biological Efficacy, and Potential Toxicity. J. Pharm. Sci. 2015, 104, 3544-3556. [CrossRef]

255. Raj, R.; Wairkar, S.; Sridhar, V.; Gaud, R. Pramipexole dihydrochloride loaded chitosan nanoparticles for nose to brain delivery: Development, characterization and in vivo anti-Parkinson activity. Int. J. Biol. Macromol. 2018, 109, 27-35. [CrossRef]

256. Liu, S.H.; Ho, P.C. Intranasal administration of brain-targeted HP- $\beta-C D / c h i t o s a n$ nanoparticles for delivery of scutellarin, a compound with protective effect in cerebral ischaemia. J. Pharm. Pharmacol. 2017, 69, 1495-1501. [CrossRef]

257. Cooper, A.; Bhattarai, N.; Zhang, M. Fabrication and cellular compatibility of aligned chitosan-PCL fibers for nerve tissue regeneration. Carbohydr. Polym. 2011, 85, 149-156. [CrossRef]

258. Kuo, Y.C.; Yeh, C.F.; Yang, J.T. Differentiation of bone marrow stromal cells in poly(lactide-co-glycolide)/chitosan scaffolds. Biomaterials 2009, 30, 6604-6613. [CrossRef] [PubMed]

259. Marchesano, V.; Gennari, O.; Mecozzi, L.; Grilli, S.; Ferraro, P. Effects of lithium niobate polarization on cell adhesion and morphology. ACS Appl. Mater. Interfaces. 2015, 7, 18113-18119. [CrossRef] [PubMed]

260. Tiffany, A.; Harley, B.A. Sequestration of biomolecules for controlled delivery in mineralized collagen scaffolds. In 42nd Society for Biomaterials Annual Meeting and Exposition 2019: The Pinnacle of Biomaterials Innovation and Excellence. Soc. Biomater. 2019, 40, 1526-7547.

261. Sallent, I.; Capella-Monsonís, H.; Zeugolis, D.I. Production and Characterization of Chemically Cross-Linked Collagen Scaffolds. In Collagen; Humana Press: New York, NY, USA, 2019; pp. 23-38.

262. Mohee, L.; Offeddu, G.S.; Husmann, A.; Oyen, M.L.; Cameron, R.E. Investigation of the intrinsic permeability of ice-templated collagen scaffolds as a function of their structural and mechanical properties. Acta Biomater. 2019, 83, 189-198. [CrossRef]

263. Liu, Y.; Nelson, T.; Chakroff, J.; Cromeens, B.; Johnson, J.; Lannutti, J.; Besner, G.E. Comparison of polyglycolic acid, polycaprolactone, and collagen as scaffolds for the production of tissue engineered intestine. J. Biomed. Mater. Res. B 2019, 107, 750-760. [CrossRef]

264. Lei, X.; Gao, J.; Xing, F.; Zhang, Y.; Ma, Y.; Zhang, G. Comparative evaluation of the physicochemical properties of nano-hydroxyapatite/collagen and natural bone ceramic/collagen scaffolds and their osteogenesis-promoting effect on MC3T3-E1 cells. Regen. Biomater. 2019, 6, 361-371. [CrossRef] 
265. Radhakrishnan, S.; Nagarajan, S.; Bechelany, M.; Kalkura, S.N. Collagen Based Biomaterials for Tissue Engineering Applications: A Review. In Processes and Phenomena on the Boundary between Biogenic and Abiogenic; Nature; Springer: Cham, Switzerland, 2020; pp. 3-22.

266. Eltom, A.; Zhong, G.; Muhammad, A. Scaffold Techniques and Designs in Tissue Engineering Functions and Purposes: A Review. Adv. Mater. Sci. Eng. 2019. [CrossRef]

267. Mohseni, M.; Castro, N.J.; Dang, H.P.; Nguyen, T.D.; Ho, H.M.; Tran, M.P.N.; Tran, P.A. Adipose tissue regeneration: Scaffold-Biomaterial strategies and translational perspectives. In Biomaterials in Translational Medicine; Academic Press: Cambridge, MA, USA, 2019; pp. 291-330.

268. Ceballos, D.; Navarro, X.; Dubey, N.; Wendelschafer-Crabb, G.; Kennedy, W.R.; Tranquillo, R.T. Magnetically Aligned Collagen Gel Filling a Collagen Nerve Guide Improves Peripheral Nerve Regeneration. Exp. Neurol. 1999, 158, 290-300. [CrossRef]

269. Dubey, N.; Letourneau, P.C.; Tranquillo, R.T. Guided Neurite Elongation and Schwann Cell Invasion into Magnetically Aligned Collagen in Simulated Peripheral Nerve Regeneration. Exp. Neurol. 1999, 158, 338-350. [CrossRef]

270. Eguchi, Y.; Ogiue-Ikeda, M.; Ueno, S. Control of orientation of rat Schwann cells using an 8-T static magnetic field. Neurosci. Lett. 2003, 351, 130-132. [CrossRef]

(C) 2020 by the authors. Licensee MDPI, Basel, Switzerland. This article is an open access article distributed under the terms and conditions of the Creative Commons Attribution (CC BY) license (http://creativecommons.org/licenses/by/4.0/). 